Research Article

\title{
The Effects of Land Use and Landscape Position on Soil Physicochemical Properties in a Semiarid Watershed, Northern Ethiopia
}

\author{
Weldemariam Seifu $\mathbb{D D}^{1,2}$ Eyasu Elias $\mathbb{D D}^{2}$ and Girmay Gebresamuel ${ }^{3}$ \\ ${ }^{1}$ Department of Horticulture, College of Agriculture and Natural Resources, Selale University, Fiche, Oromia, Ethiopia \\ ${ }^{2}$ Center for Environmental Sciences, Addis Ababa University, Addis Ababa, Ethiopia \\ ${ }^{3}$ Department of Land Resources Management and Environmental Protection, Mekelle University, Mekelle, Tigray, Ethiopia
}

Correspondence should be addressed to Weldemariam Seifu; weldemariam.seifu@aau.edu.et

Received 27 April 2020; Revised 11 November 2020; Accepted 21 November 2020; Published 2 December 2020

Academic Editor: Teodoro M. Miano

Copyright (c) 2020 Weldemariam Seifu et al. This is an open access article distributed under the Creative Commons Attribution License, which permits unrestricted use, distribution, and reproduction in any medium, provided the original work is properly cited.

\begin{abstract}
Understanding topography effects and assessing the soil properties in different land use is an essential first step for sustainable soil management. Hence, land use type and altitudinal gradient on selected soil parameters were studied in Ayiba watershed, northern Ethiopia. Thirty composite soil samples were collected from 0 to $30 \mathrm{~cm}$ of soil depth under four land use types across three altitudinal gradients and were analyzed for selected soil parameters following the standard procedures. A significant main effect of land use and altitudinal gradient on the content of the soil particles was noted. Results also indicated that the bulk density (BD), total porosity (TP), and $\mathrm{P}_{\mathrm{av}}$ of the soil are significantly different $(p<0.05)$ in the watershed because of land use type and altitudinal gradient. Barren land and higher altitude landscapes have the highest $\mathrm{BD}$, and the lowest TP, and grassland and lower altitude landscapes have the lowest $\mathrm{BD}$ and high TP. Intensive cultivation accompanied by natural land conversion and erosion due to the rugged landscape nature caused high $\mathrm{BD}$ and low TP. Analysis of variance results also shows the significant interaction effect of land use type and altitudinal gradient on EC, SOM, SOC $(p<0.001)$, and $\mathrm{pH}$-water $(1: 2.5)$, and TN $(p<0.01)$. The Pearson correlation of SOM with TP, TN, MC, and clay content showed a strong positive relationship. But, SOC, TN, and clay content were negatively correlated with BD. Soils of the study watershed are found in low to optimum rating levels in their selected physicochemical properties. Overall, the results show that land use and topography gradient significantly affected soil physicochemical properties in the study watershed. Therefore, soil management options should focus on scenarios that could improve the soil conditions to enhance crop production on a sustainable basis.
\end{abstract}

\section{Introduction}

The optimally integrated coexistence of principal natural assets (viz., soil water and vegetation) is vital for maintaining terrestrial ecosystem functions and productivity [1]. Remarkably, the soil, an essential resource of nature and a significant component of the terrestrial ecosystem, plays a vital role in upholding the trio known as NPK and other plant nutrients (https://www.dpi.nsw.gov.au). However, the base of this vitally important natural capital is becoming vulnerable to declination and deteriorating over time [1-3] and manifested in land/soil degradation. The deriving agent includes high population pressure, excessive livestock pressure of grassland areas, changes in land use, inappropriate agricultural practices, massive deforestation of natural forest (farm expansion, fuel, and construction), agricultural expansion (cultivation of steep slopes and marginal areas), and rugged nature of the landscape [4-8].

Soil properties varied significantly among soil types and across locations reflecting differences in parent materials, climate, and land use [4]. The northern region and the most highland parts of Ethiopia are among the most seriously affected areas by land/soil degradation [9-12]. Factors are aggravating land/soil degradation resulting in low soil 
fertility manifested in lower yield and higher environmental problems [13]. Bekunda et al. [14] specially narrated this situation as "the soil fertility decline is not out of the smallholder farmers' violation, but rather the consequence of striving for household well being under difficult circumstances."

The food insecurity and rural poverty in the African smallholder farming system are due to soil nutrient depletion. Pomeroy et al. [15] observed a remarkable decline in soil nutrients due to the deterioration of chemical, physical, and biological properties in East Africa. The main reasons for the decline, besides soil erosion, are a decline in soil organic matter and soil biological activity, degradation of soil structure and loss of other soil physical qualities, reduction in the availability of significant macronutrients $(\mathrm{N}$, $\mathrm{P}, \mathrm{K}$ ) and micronutrients, and increased toxicity due to acidification and salinization [16]. A previous study also confirmed the fact of this negative soil nutrient balance, mainly soils organic carbon by $0-63 \%$ following deforestation in sub-Saharan Africa [17] and macronutrients of $(\mathrm{N}$; $\left.-22,-122 \mathrm{~kg} \mathrm{ha}^{-1}\right),\left(\mathrm{P} ;-2.5,-13 \mathrm{~kg} \mathrm{ha}^{-1}\right)$, and $(\mathrm{K} ;-15$, $-82 \mathrm{kgha}^{-1}$ ) in Africa and Ethiopia, respectively (the numbers in parenthesis). The negative soil nutrient balance indicates that the primary soil nutrients are already mined exhaustively $[18,19]$ because of the limitation on sustainable management practices based on the soil system's understanding. Above all, soil properties' overall status in a given landscape is controlled mainly by the type of land use system applied. The demand for arable land, grazing, forestry, wildlife, tourism, and community development is more remarkable than land resources available, so that soil quality may worsen [20]. Hence, the soil needs to be protected sustainably without compromising current or future generations' ability to meet their needs.

Characterizing the spatial variability of soil nutrients concerning site properties, including climate, land use, landscape position (topography), and other variables, is vital for a comprehensive understanding of how the ecosystems work and assessing the effects of future land use change on soil nutrients $[21,22]$. Henceforth, under a small watershed scale, topography and land use types may be the dominant factors determining soil properties' status [23, 24], particularly in areas of multiple land use and complex topography. Accordingly, quantifying the pattern and spatial distribution of basic soil indicators is fundamental to understanding many ecosystem processes. For example, determining the spatial distribution of soil organic carbon is an essential factor in land management decision making, climate change mitigation, and landscape planning [25]. Therefore, landscape-based management, protection, and soil restoration are essential for several environmental and policy reasons.

Topography and land use types are vital factors affecting soil property variability [26]. The topography is a significant factor controlling both hydrological and soil processes at the landscape scale, and its influence is also apparent in the soil catena concept [27]. Environmental factors such as slope aspect induced by microclimate differences, topography, parent materials, and vegetation communities are significantly influenced by the spatial variation of soil properties
[28]. Amuyou and Kotingo [29] reported that slope gradients have a marked influence on soil properties expressed in the soils' distribution along with slope positions. Soil moisture and soil chemistry could affect plant growth, and their distributions on specific ecosystems are governed by topographic attributes [27, 30]. Concerning topographic positions, significant variation for clay, bulk density, organic matter, and total nitrogen was observed [26] in China's loess hilly area. According to Ezeaku and Eze [31], higher CEC, $\mathrm{OM}$, and TN values were recorded along with the slope compared to the upslope position. Many other authors also reported the influence of topography on soil texture, organic carbon, and CEC [32-34] in Africa. Landscape features in most parts of Ethiopia influence soil resources, including depth; thus, cultivation practices aggravate reduced crop production because soil erosion is a function of steep slopes and land use in mountainous areas. Hence, there is a need to improve these tendencies, which lies in the improvement of the agricultural sector's long-term development.

Besides, changes in land use and its alterations on the ecosystem can significantly affect soil physical, chemical, and biological properties [35, 36]. Beyene [37] reported that, in southern Ethiopia, soils of cultivated lands have higher available phosphorus (P) content, whereas exchangeable bases, OC and CEC, were higher in grasslands. Reduction of $\mathrm{OM}$, available phosphorus, and porosity was observed due to the change of land use from forest to cultivation, while a reverse trend was examined for $\mathrm{BD}$ and $\mathrm{pH}[35,38]$. In a meta-analysis of soil carbon sequestration in agroforestry systems, SOC stocks were found significantly reduced when a pasture/grassland was converted into an agrisilvicultural system. Significant SOC stocks increases were also reported at various soil horizons and depths in the land use change from agriculture to agrisilviculture, forest plantation to silvopasture, and uncultivated/other to agrisilviculture [39]. The study conducted by $\mathrm{Hu}$ et al. [26] revealed that forest land use has higher soil OC, TN, and CEC than a cultivated land use system. Many investigations indicated that SOC and other plant nutrients are the soil properties most affected by cultivation over time. Thus, the decline in yield has been attributed to the loss of plant nutrients by plant removal, erosion, leaching, and deterioration of soil physical condition [18]. Majule [40] further justified that soils in areas with continuous cultivation and without appropriate management practices have low fertility levels due to overutilization. The linkage between land use land cover and soil fertility in Kenya and Tanzania across altitudinal gradients was assessed, and higher phosphorus $(\mathrm{P})$ was reported in the lower zones than the middle and upper zones [15, 41]. Cleaning the natural forest in most parts of the upper zones for cultivation has contributed significantly to the reduced level of SOC, N, P, and K in the soil [40].

Soil nutrient depletion and related low agricultural productivity are severe problems in Ethiopia and has forced farmers to abandon their fields and convert into woodlots dominated with Eucalyptus spp. Agricultural activities such as tillage, fertilization, and biomass alteration lead to fundamental changes in the pools and fluxes of carbon (C), nitrogen $(\mathrm{N})$, and phosphorus $(\mathrm{P})$ that initially existed in 
native ecosystems [42]. Besides, land use change, mainly through the conversion of natural vegetation to cropland and grazed pastures, may influence many ecological properties [43], such as soil carbon dynamics and soil microbial properties [44]. Moreover, land cover changes and deforestation associated with agricultural expansion are among the most significant contributors to anthropogenic carbon emissions worldwide [45]. Thus, in decision making on sustaining agricultural production and land degradation mitigation, a local inventory of soil properties to understand the spatial distribution is essential. A reasonable way of deriving the evidence is using proxy environmental features that have established relationships with the soil properties (e.g., land use and topography gradient factors used in this study). Spatially explicit data on land use and topography effects on soil properties are limited in the study watershed. There is, therefore, a need to assess the status of soil physicochemical properties between landscape positions of each land use types for sound management of land resources and enhance sustainable crop productivity at the watershed level. Therefore, the main objective of this study was to (i) examine the influence of different land use types on soil physicochemical properties at landscape scale and (ii) evaluate selected soil physicochemical properties along the toposequence (lower-middle-upper sequence).

\section{Materials and Methods}

2.1. Description of the Study Area. Ayiba watershed is part of the Denakil River basin and geographically located between $12^{\circ} 51^{\prime} 18^{\prime \prime}-12^{\circ} 54^{\prime} 36^{\prime \prime} \mathrm{N}$ and $39^{\circ} 29^{\prime} 24^{\prime \prime}-39^{\circ} 35^{\prime} 24^{\prime \prime} \mathrm{E}$ (Figure 1). It covers an area of about 4099.14 ha. The elevation of the watershed ranges from 2722 to 3944 meter above sea level. The area's topography is a mountainous and hilly dissected terrain with steep slopes and undulating topography, which characterizes the middle and upper parts, whereas gentle slopes form the lower parts of the study watershed. The soil parent materials of Emba Alaje District (southern Tigray), where the study watershed is situated, are of igneous rock of primary class (I), basic igneous group (IB) of basaltic type (IB2), which are deeply weathered [46]. The major reference soil groups (FAO guideline based) of the study area are Leptosol, Vertisols, Cambisols, and Fluvisols [46]. The area's climate is generally characterized as a subtropical continental type with an extended dry period of nine to ten months, and the maximum rainy days last for 50-60 days [46]. The watershed's 20 years of weather data were estimated from four active nearby weather stations (Bora, Maychew, Wedisemero, and Korem) of the Ethiopia National Meteorological Agency. Accordingly, the study area receives a mean monthly rainfall of $72.88 \mathrm{~mm}$ and a total annual rainfall of $875 \mathrm{~mm}$. The rainfall pattern in the area is bimodal, with a high amount of rainfall occurring during the primary rainy season (locally called "Kiremti") lasting between July and September, and the short rainy season extends from March to June. April is the peak period of the small rain (59.94 mm), and August is the peak for the "Kiremti" season $(262.54 \mathrm{~mm})$. Similarly, the mean minimum and maximum monthly temperatures of the area are 7.1 and $25.6^{\circ} \mathrm{C}$, respectively, with a mean of $16.8^{\circ} \mathrm{C}$ (Figure 2 ).

2.2. Current Land Use Cover. Land use and land cover change data provide essential information for environmental management and planning [48]. The current land uses are generally rainfed agriculture and livestock (grazing) dominated by degraded shrublands [46]. Landsat_8 OLITIRS-30 m resolution was derived from open access Landsat imagery service (https://earthexplorer.usgs.gov/), acquired with path 168 and row 51 in the dry season (28 February 2017), when spectral differences between land cover types are most significant, and cloud contamination is minimal. To assure that all pixels were precisely aligned and conducted image-to-image coregistration before the classification in the data preprocessing using ENVI software (Exelis Visual Information Solutions, Boulder, Colorado). Data were projected to the Universal Transverse Mercator (UTM) projection system zone $37 \mathrm{~N}$ and data of World Geodetic System 84 (WGS84), ensuring consistency between datasets during analysis.

The watershed boundary was delineated using Arc hydro tool, and finally, the land use/land cover map of the study watershed was produced in ArcGIS 10.5 environ. Accordingly, four major land use types (barren land, cultivated land, grassland, and plantation forest) of the watershed were identified (Figure 3, Table 1). To generate a training data set for our supervised classification, we identified pure pixel patches of each land use type by visually interpreting Landsat images and high-resolution imagery from Google Earth.

2.3. Soil Sampling and Laboratory Analysis. Before soil sampling, an interview with residents and field observation was conducted to investigate the watershed land use history. Land use types and elevation variations were surveyed before soil samples were collected. Three composite soil samples prepared following the coning and quartering method [49] (0-30 cm depth, each sample consisting of fifteen subsamples) were collected using a hand auger $\left(100 \mathrm{~cm}^{3}\right)$ for each land use type across topography in the watershed in 2017 offseason from 20 January to 30 February. The three topographic gradient categories are lower (2722-2800), middle (2800-3100), and upper (3100-3944), respectively. A global positioning system (GPS) was used to identify the site's longitude, latitude, and elevation.

Soil sampling sites were selected by stratifying the watershed. Three random strata were aligned vertically along the toposequence from the bottom to the top edge elevation of the mountain, and major adjacent land use types in each stratum across the altitude were identified (four at upper and middle elevation (BL, CL, GL, and PF) and two at a lower elevation (CL and GL). The soil sample was taken $10 \mathrm{~m}$ before and $10 \mathrm{~m}$ after the border between adjacent land use and $\sim 150 \mathrm{~m}$ away from the outer ridge to avoid edge effects. At each sampling spot, surface litter is scraped, vegetation cover is removed before collecting samples, and sample spot excluding was performed if the considerable difference is noted to minimize soil variability. For bulk density, the 


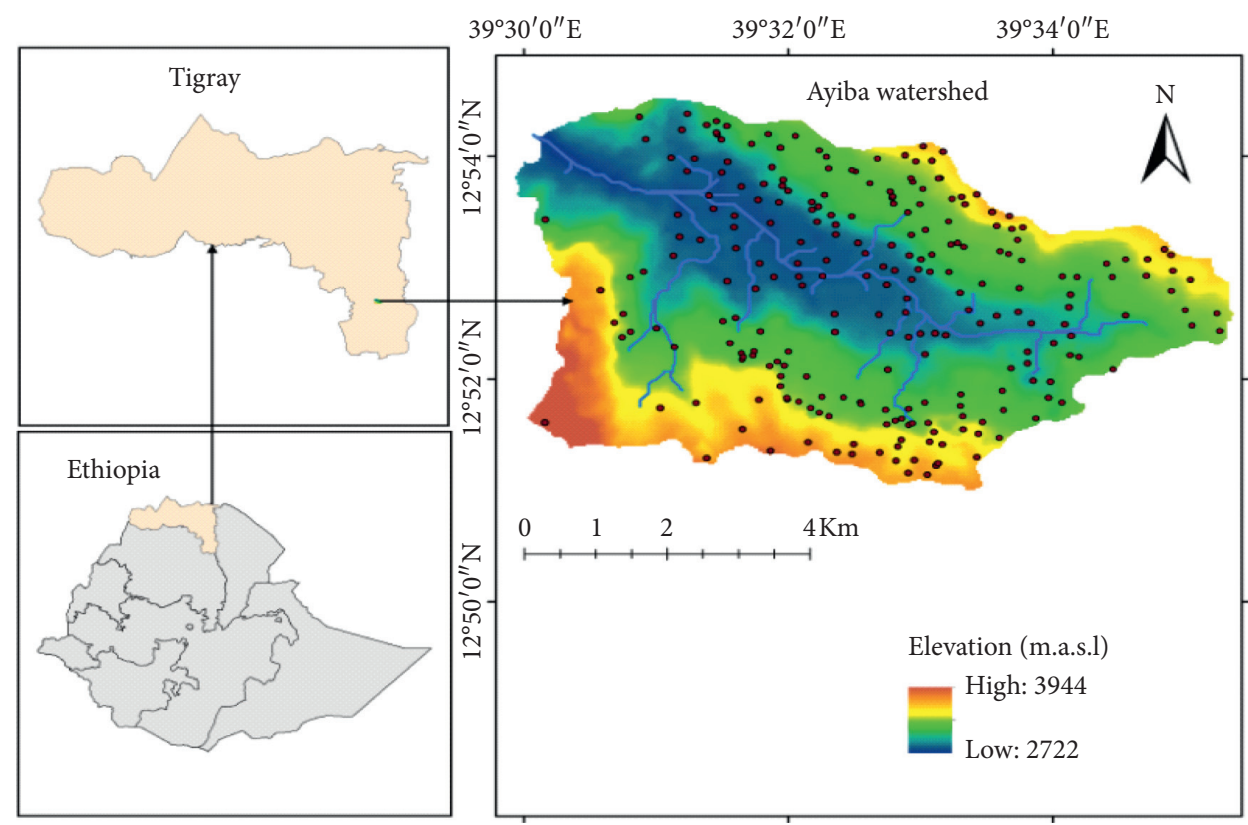

- Sampling points

- Stream

(a)

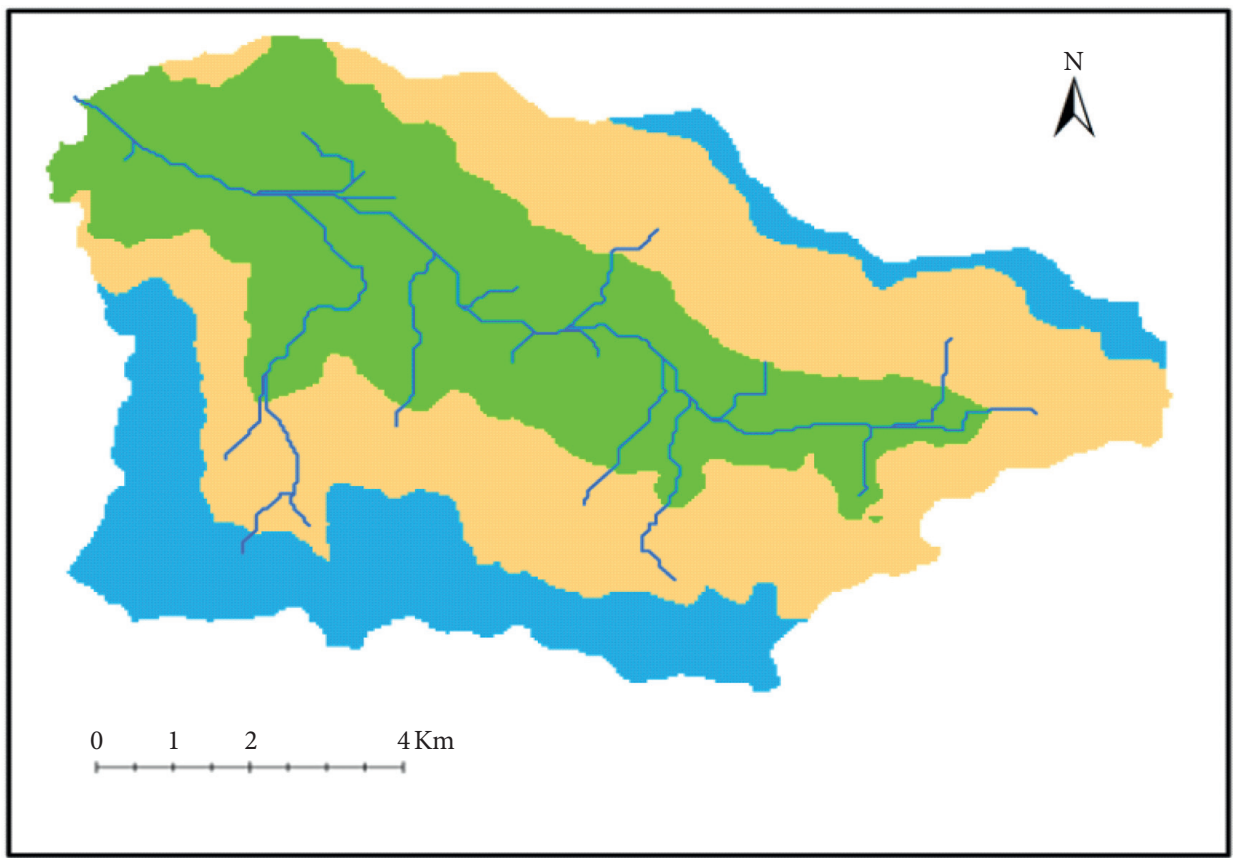

Elevation (m.a.s.l)
$\square$ Upper (3100-3944)

— Stream

Middle (2800-3100)

Lower (2722-2800)

(b)

FIgURE 1: Map of the study watershed showing (a) the location and distribution of soil sampling points and (b) topographic classes.

cylindrical core method [50] were used to collect undisturbed samples, and a total of 30 undisturbed soil samples were collected by taking three core samples from each land use type along with each topographic class. The samples were air-dried, ground, sieved to remove gravel fractions ( $>2 \mathrm{~mm}$ ), weighed, and prepared as required for final laboratory analysis [51]. Laboratory work was carried out at the Tigray Soil Laboratory Centre, Mekelle, Ethiopia, and at the 


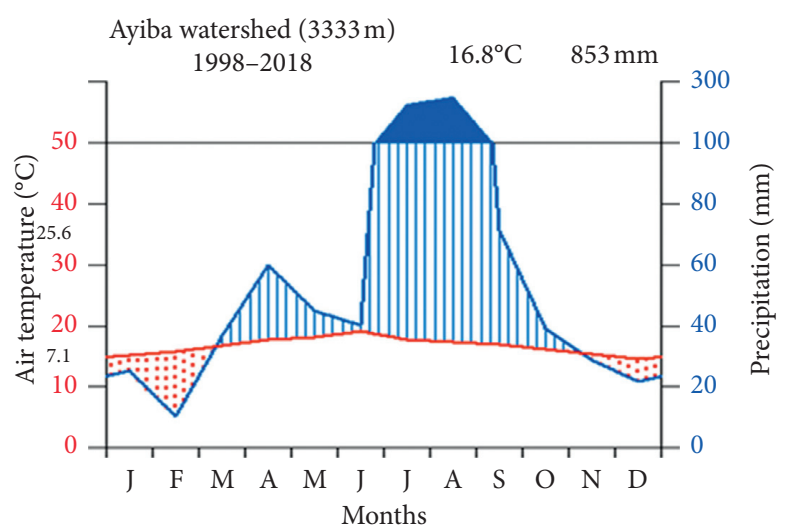

Figure 2: Climate diagram of the Ayiba watershed (data source: NMSAE [47]).

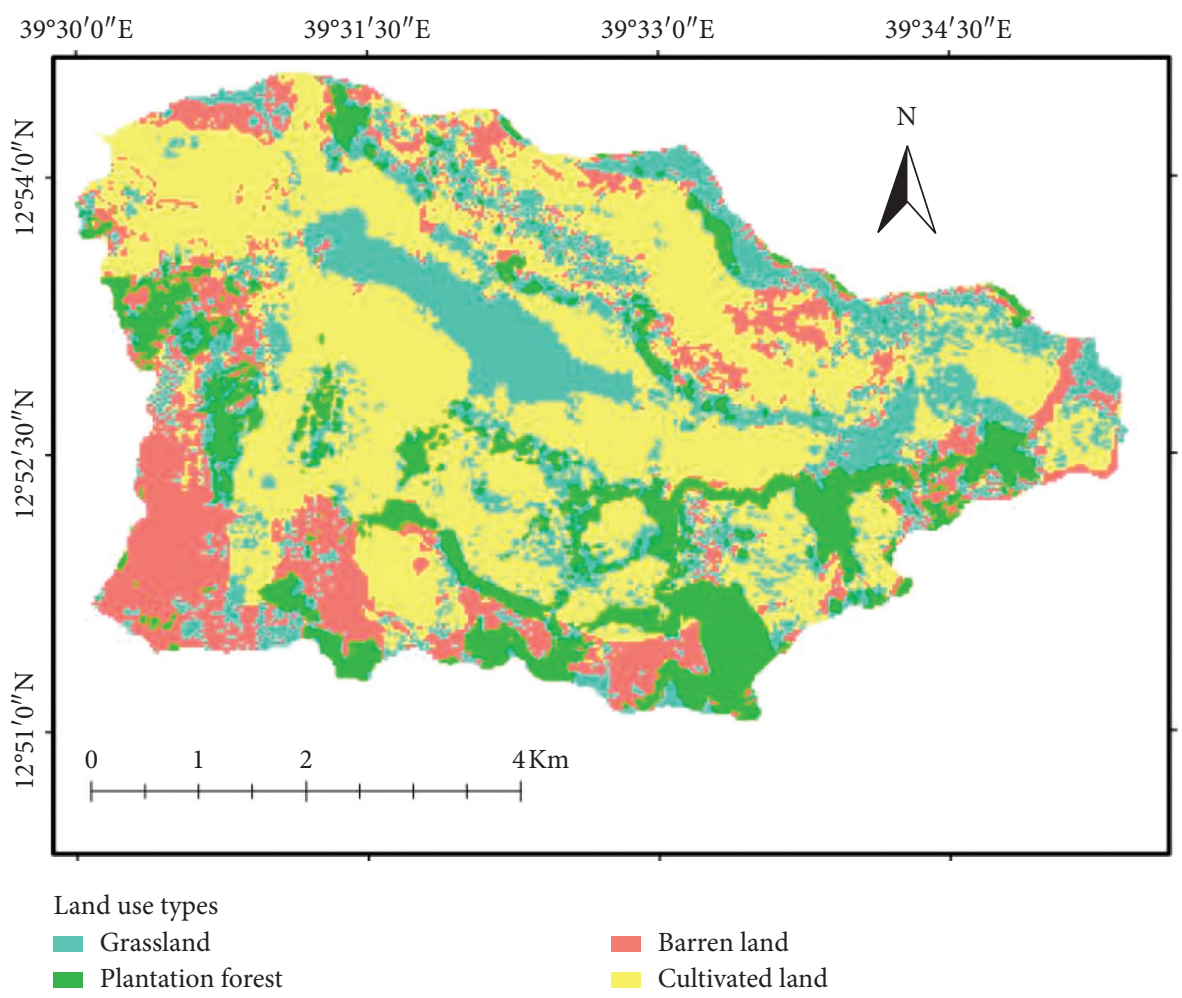

FIGURE 3: Land use map of the study watershed for the year 2017.

TABLE 1: Description of major land use types.

\begin{tabular}{lc}
\hline Land use types & Description \\
\hline Barren land (BL) & The area covered by degraded lands, bare soils, roads, and rocks \\
Cultivated land (CL) & The area used for annual crop production (main crops include wheat, barley, teff, and pea) and habitation \\
Grassland (GL) & The area used for both communal free grazing and cut-and-carry system (partial exclosures) \\
Plantation forest (PF) & The area covered by plantation forest (Eucalyptus) and natural forest (church forest)
\end{tabular}

plant nutrition laboratory, college of environmental science resources, Zhejiang University, China.

The chemical analysis for organic carbon was performed by drying samples in an oven at $105^{\circ} \mathrm{C}$ and subsequently burning using the loss-on-ignition (LOI) method at $400^{\circ} \mathrm{C}$ [52] to determine soil organic matter. Then, SOM was converted into soil organic carbon according to equation (2) by multiplying the obtained estimated SOM from equation 
(1) with the "van Bemmelen factor" of 0.58, as described in the work of Brady and Weil [53] and Guo and Gifford [54].

$$
\begin{aligned}
\operatorname{SOM}_{\mathrm{LOI}}(\%) & =\frac{\left(W_{105^{\circ} \mathrm{C}}-W_{400^{\circ} \mathrm{C}}\right)}{W_{105^{\circ} \mathrm{C}}} \times 100, \\
\operatorname{SOC}(\%) & =\operatorname{SOM}(\%) * 0.58,
\end{aligned}
$$

where $\mathrm{SOM}_{\mathrm{LOI}}$ : soil organic matter of loss on ignition, $W_{105^{\circ} \mathrm{C}}$ : the weight of soil before combustion (preignition) after oven-dried at $105^{\circ} \mathrm{C}$ and $W_{400^{\circ} \mathrm{C}}$ : the weight of soil after combustion (postignition) at $400^{\circ} \mathrm{C}$, and SOC: soil organic carbon.

2.4. Statistical Analysis. Soil data obtained from the laboratory work were analyzed using SPSS (version 26 for Windows). Descriptive statistical analyses were conducted using this software. Two-way ANOVA was used following the general linear model (GLM) procedure, where land use types and landscape positions (altitude) were independent variables (factors) and the selected soil physicochemical properties were dependent variables. Post hoc tests for each variable were performed when the variance analysis showed statistically significant differences at $p \leq 0.05$ level of probability. For statistically different parameters at probability 5\%, means were separated using Duncan's test. Pearson correlation analysis was conducted to determine the correlation between all the measured parameters with $\mathrm{R}$ "corrplot package" [55].

\section{Results and Discussion}

3.1. Statistical Analysis of the Selected Soil Physicochemical Properties. The descriptive analyses revealed a numerical difference among the selected physicochemical soil parameters among land use types across altitudinal gradients. The variance analysis also showed significant statistical variation among the selected measured soil physicochemical parameters due to variation in land use type and altitude factors. As shown in Table 2, there was a significant main effect variation in terms of land use and altitudinal gradient on sand fraction and soil moisture $(p<0.001)$, in terms of land use alone on silt fraction $(p<0.011)$ and clay fraction $(p<0.01)$, whereas $\mathrm{BD}, \mathrm{TP}$, and $\mathrm{P}_{\mathrm{av}}(p<0.05), \mathrm{pH}-\mathrm{H}_{2} \mathrm{O}(1$ : $2.5)(p<0.01), \mathrm{EC}, \mathrm{SOM}, \mathrm{SOC}, \mathrm{TN}$, and $\mathrm{C}: \mathrm{N}(p<0.001)$ were found strongly dependent on land use, topographic positions, and their interactions. However, $K_{\text {exch }}$ did not show any significant difference with land use $(p>0.05)$, altitude $(p>0.05)$, or their interaction $(p>0.05)$ (Table 2$)$.

\subsection{The Effect of Land Use and Altitudinal Gradient on Selected Soil Physical Properties}

3.2.1. Soil Particle Size Distribution. The variance analysis revealed that all the land use types' textural class was clay, indicating the similarity in the watershed parent material. The mean sand content ranged from $17.93 \pm 1.63 \%$ to $29 \pm 6.55 \%$ across altitude and from $22.95 \pm 1.03 \%$ to $37.24 \pm 1.26 \%$ among land use types. Along with the altitudinal range, high clay content was noted. Across altitude, mean silt and clay contents were found in the range of $25.35 \pm 45$ to $30.73 \pm 2.01$ and $44.68 \pm 4.81$ to $51.34 \pm 3.07$, respectively (Figure 4), with the highest record at GL and lowest record at $\mathrm{BL}$. The highest clay content at GL may be due to the change in land use from the communal-free intensive grazing system to a partially (periodical) protected grazing system and managed cut-and-carry system (personal communication with development agents, 2018). This practice positively contributes to accumulating the fine clay particles in GL. Barren land showed a higher sand percentage, which may be due to vegetation clearance and erosion. Elias [57] confirms that although the texture is an inherent soil property, land use practices can be altered over a more extended period. Other studies also reported that silt and clay particles were found to be significantly $(p \leq 0.05)$ affected by land use types in Kuyu district, Ethiopia [58].

Relatively high sand contents were observed at the upper topography compared to the lower topography, and along with the soil catena, the distribution of sand fraction was in the following order: upper altitude $>$ middle altitude $>$ low altitude (Figure 4), indicating that sand content decreases down toposequence. Because erosion is a selective process that can remove clay particles leaving the coarse fragments behind and sedimenting downstream (Figure 5), likewise, others observed a decrease in fine fractions and a corresponding increase of sand content in the steeper slope due to the selective removal of fine particles by water [32, 59]. In Ethiopia and elsewhere, similar results have been reported as significantly higher fine soil textural fractions in the low slope gradient than the upper ones [57, 60,61]. Many other authors also support this result, revealing that deforestation, farming practices, and intensive grazing systems have changed soil texture by aggravating soil erosion [62, 63]. Charan et al. [64] added another possible justification as sand fraction may increase with elevation due to the abundance of sand-forming minerals in parent material at the higher topographic position.

3.2.2. Soil Bulk Density, Total Porosity, and Moisture Content. The mean value for soil bulk density (BD) varied from 0.98 to $1.40 \mathrm{~g} \mathrm{~cm}^{-3}$, with the highest mean value recorded in the upper topography and the lowest in the lower topography under barren land (BL) and grassland (GL), respectively (Table 2 ). High $\mathrm{BD}$ values in $\mathrm{BL}$ might be attributed to deforestation, compaction by animals trampling, continuous erosion, and low organic matter input. The lowest $\mathrm{BD}$ at the lower altitude than the other landscape position might be due to managed use of the GL area (cutand-carry system) since 2004. This practice decreases intensive free grazing and livestock trampling effect and positively contributes to reducing $\mathrm{BD}$ due to its relatively highest soil organic matter input from above-ground and below-ground grass biomass. Besides, erodible mineral deposits are transported principally by water as the erosive agent from upper and middle streams, which reduces BD in the lower altitude. The cut-and-carry system is also clearly attributable to the high addition of soil organic matter, 
TABLE 2: Analysis of variance summary results for selected soil physicochemical properties in different land use types and altitudinal gradients.

\begin{tabular}{|c|c|c|c|c|c|c|c|c|c|c|c|c|}
\hline \multirow{2}{*}{ Soil variables } & \multicolumn{4}{|c|}{ Land use types (LU) } & \multicolumn{4}{|c|}{ Altitudinal gradient (A) } & \multicolumn{4}{|c|}{$\mathrm{LU} * \mathrm{~A}$} \\
\hline & Tean square & $\mathrm{d} f$ & $F$-stat & Sig. & Mean square & $\mathrm{d} f$ & F-stat & Sig. & Mean square & $\mathrm{d} f$ & $F$-stat & Sig. \\
\hline Sand (\%) & 205.099 & 3 & 21.634 & $0.001^{* * *}$ & 139.051 & 2 & 14.667 & $0.001^{* * *}$ & 9.608 & 4 & 1.013 & $0.424^{\mathrm{ns}}$ \\
\hline Silt (\%) & 65.430 & 3 & 4.831 & $0.05^{*}$ & 35.147 & 2 & 2.595 & $0.100^{\mathrm{ns}}$ & 12.397 & 4 & 0.915 & $0.474^{\mathrm{ns}}$ \\
\hline Clay (\%) & 122.918 & 3 & 7.845 & $0.01^{* *}$ & 47.629 & 2 & 3.040 & $0.070^{\mathrm{ns}}$ & 33.913 & 4 & 2.165 & $0.110^{\text {ns }}$ \\
\hline Soil moisture (\%) & 50.117 & 3 & 9.716 & $0.001^{* * *}$ & 80.275 & 2 & 15.562 & $0.001^{* * *}$ & 2.314 & 4 & 0.449 & $0.772^{\text {ns }}$ \\
\hline Bulk density $\left(\mathrm{g} \mathrm{cm}^{-3}\right)$ & 0.043 & 3 & 18.161 & $0.001^{* * *}$ & 0.090 & 2 & 38.540 & $0.001^{* * *}$ & 0.007 & 4 & 3.071 & $0.05^{*}$ \\
\hline Total porosity (\%) & 60.151 & 3 & 18.215 & $0.001^{* * *}$ & 127.624 & 2 & 38.647 & $0.001^{* * *}$ & 10.212 & 4 & 3.092 & $0.05^{*}$ \\
\hline $\mathrm{pH}-$ & & 3 & 45. & 0. & & 2 & & $*$ & & 4 & 5. & $0.01^{* *}$ \\
\hline $\mathrm{EC}\left(\mathrm{mS} \mathrm{cm}{ }^{-1}\right)$ & 04 & 3 & 315 & & 0.017 & 2 & & $0.001^{* * *}$ & 0.007 & 4 & 22.168 & $0.001^{* * *}$ \\
\hline SOM (\%) & 2.011 & 3 & 70.746 & $0.001^{* * *}$ & 3.151 & 2 & 110.818 & $0.001^{* * *}$ & 1.047 & 4 & 36.833 & $0.001^{* * *}$ \\
\hline SOC ( & 0.676 & 3 & 70.746 & $0.001^{* * *}$ & 1.060 & 2 & 110.962 & $0.001^{* * *}$ & 0.352 & 4 & 36.843 & $0.001^{* * *}$ \\
\hline $\mathrm{TN}(\%)$ & 0.002 & 3 & 5.030 & $0.009^{* *}$ & 0.002 & 2 & 3.870 & $0.05^{*}$ & 0.008 & 4 & 20.694 & $0.001^{* * *}$ \\
\hline $\mathrm{C}: \mathrm{N}$ & 21.780 & 3 & 16.283 & $0.001^{* * *}$ & 16.366 & 2 & 12.236 & $0.001^{* * *}$ & 13.181 & 4 & 9.855 & $0.001^{* * *}$ \\
\hline $\mathrm{P}_{\mathrm{av}}(\mathrm{m}$ & 105.143 & 3 & 3.892 & $0.024^{*}$ & 265.950 & 2 & 9.845 & $0.01^{* *}$ & 82.625 & 4 & 3.059 & $0.05^{*}$ \\
\hline $\mathrm{K}_{\text {exch }}\left(\mathrm{cmol}(+) \mathrm{kg}^{-1}\right)$ & 0.072 & 3 & 1.177 & $0.343^{\text {ns }}$ & 0.029 & 2 & 0.482 & $0.625^{\mathrm{ns}}$ & 0.052 & 4 & 0.861 & $0.504^{\mathrm{ns}}$ \\
\hline
\end{tabular}

$*^{*}, *$, and ${ }^{* * *}$ indicate significance at $p<0.05, p<0.01$, and $p<0.001$, respectively. ns: not significant at $p<0.05, \mathrm{~d}$ f: degree of freedom, SOM : soil organic matter, SOC: soil organic carbon, TN : total nitrogen, $\mathrm{C}: \mathrm{N}$ : carbon-to-nitrogen ratio, $\mathrm{P}_{\mathrm{av}}$ : available phosphorus, $\mathrm{K}_{\text {exch: }}$ exchangeable potassium.
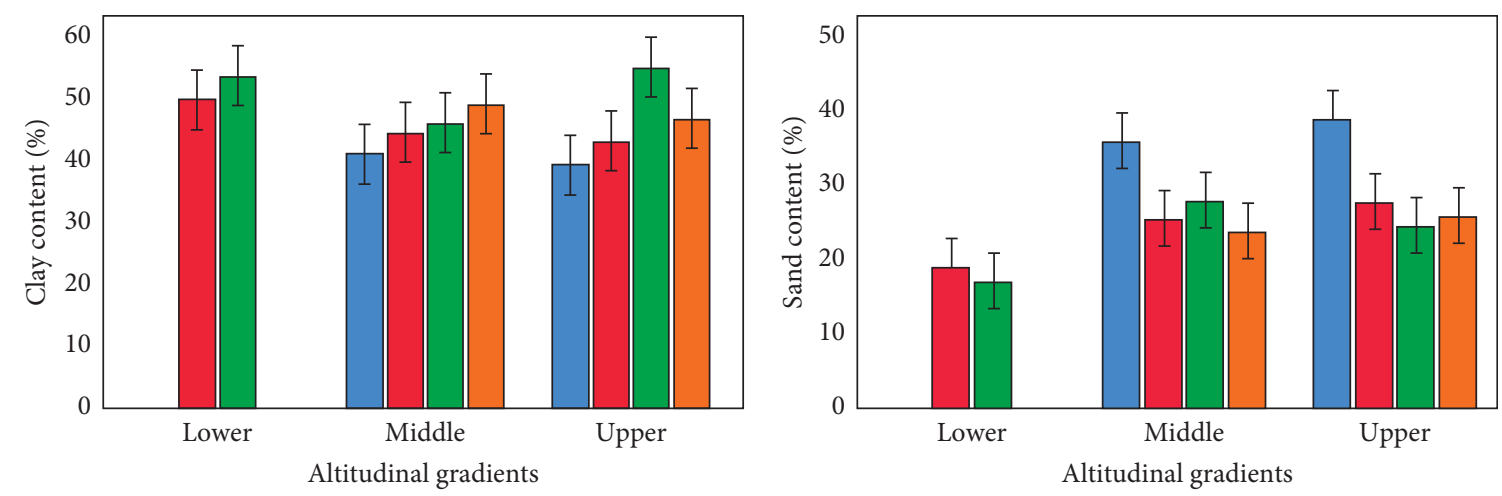

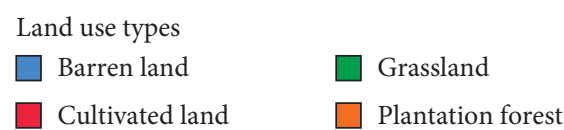

(a)

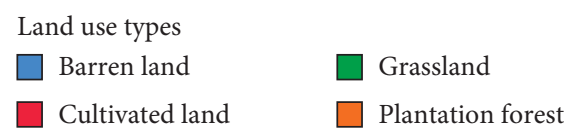

(b)

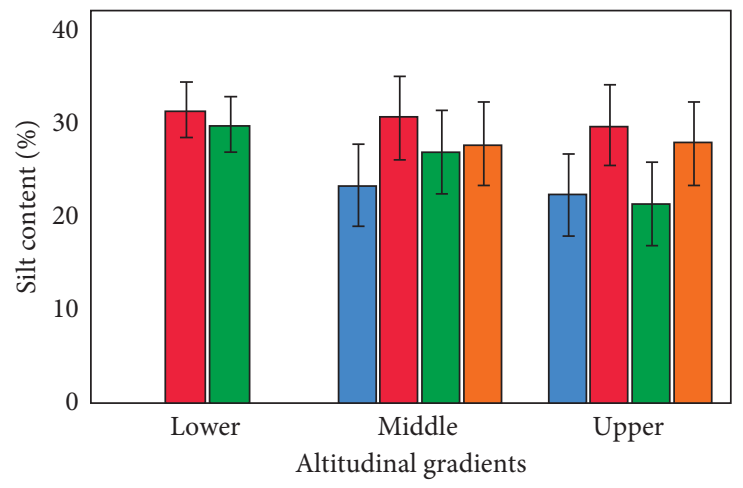

Land use types

Barren land

Grassland

Cultivated land

Plantation forest

(c)

FIgURE 4: Soil particle size distribution (fraction of sand, silt, and clay) in different land use types across the altitudinal gradients. 


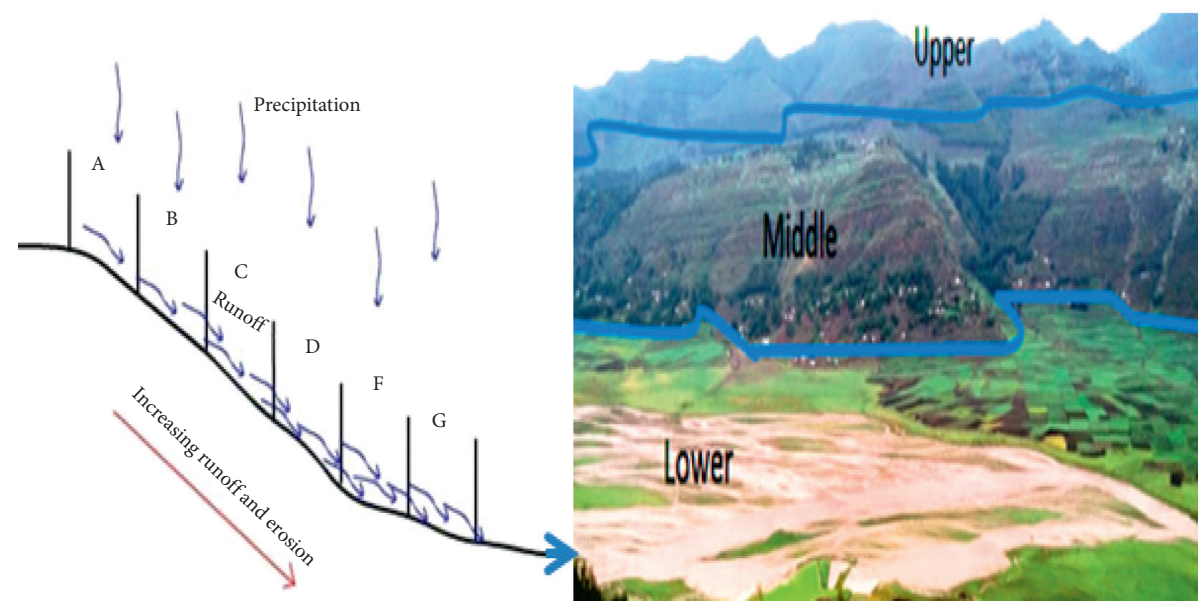

(a)

(b)

FIgURE 5: (a) Model sketch for hillslope position and runoff. (b) Flooding at the lower part of the Ayiba watershed during the rainy season (photo courtesy: weldemariam, July 2018).

which increased soil organic carbon and decreased BD of the surface soil reported by previous studies $[1,65,66]$. Similarly, the lowest BD in GL due to the higher clay content and less disturbance of the soil under grassland was reported [58]. Contrary to this argument, Lelisa and Abebaw [67] reported higher $\mathrm{BD}$ in the GL than the adjacent $\mathrm{BL}$ and rehabilitated land in the Jigessa rehabilitation site, Borana zone, Ethiopia.

The higher BD in GL of the middle topography than the upper topography indicates that soil compaction was enhanced due to free overgrazing pressure, and livestock disturbance over trampling, especially during the rainy season. The result of this study is in correspondence with the result of the work of Pei et al. [68] and others who revealed $\mathrm{BD}$ often increases in soils under heavy grazing pressure by animal trampling, poaching, and pugging [66, 69-72]. Recently, Shiferaw et al. [73] added that the lower BD in enclosure land use type resulted from fewer disturbances, higher litterfall, and organic matter accumulation, which indicated better management that led to better soil organic carbon sequestration. Raiesi and Riahi [74] also reported that heavily grazed rangelands had a more significant (22\%) $\mathrm{BD}$ than ungrazed rangelands in central Iran. Moreover, Mekuria et al. [75], who studied exclosures' role to restore degraded soils in Tigray due to overgrazing, stated that exclosures lead to a restoration of natural resources such as soil fertility, vegetation biomass and composition, fauna, and water storage. The topsoil $\mathrm{BD}$ of the study watershed was found below the typical value suggested by Hazelton and Murphy [76] for agricultural soil, signifying that there is less soil compaction or restriction for root development. Generally, in the present study, an increasing BD trend was observed as elevation increases and followed the Upper $>$ Middle $>$ Lower order (Table 3). Contrary to this finding, Ahmad and Somaiah [77] have reported a decreasing bulk density trend with increase in altitude.

The mean values of total porosity (TP) under different land use types, namely, BL, GL, cultivated land (CL), and plantation forest (PF), were 48.56, 54.55, 57.08, and 55.45\%, respectively, and the mean value of TP across topographic classes, namely, upper, middle, and lower, was 51.79, 53.46, and $60.96 \%$, respectively (Table 4 ). The mean values for $\mathrm{TP}$ across the watershed varied from 47.44 to $63.06 \%$, with the highest TP in the lower landscape position under GL (63.05\%) and the lowest TP in the upper landscape position under BL (47.44\%) (Table 3). These differences might have occurred due to continuous livestock movement for grazing purposes in grassland soils and due to erosion, which exhibits higher $\mathrm{BD}$ and lower porosity. The highest $\mathrm{TP}$ at lower topography, in PF at the middle topography, and in GL at upper topography could be accredited by high organic matter contents and low BD. Similarly, Gupta [78] and Brady and Weil [79] revealed that the number of pore spaces and soil organic matter is inversely related to $\mathrm{BD}$, and all factors that affect soil pore spaces will also have effects on $\mathrm{BD}$. Hence, a decrease in porosity may be due to a reduction in organic matter content.

In this study, the soil moisture of GL recorded the highest mean value, which was statistically at par with CL and PF, whereas the soil of BL had the least mean value (Table 3). The mean soil moisture content of the studied land uses of the watershed followed GL $>\mathrm{CL}>\mathrm{PF}>\mathrm{BL}$. Because of the topographic gradient, soil moisture was higher at lower topography (Table 3), which may be ascribed to higher soil clay fractions with possibly good soil structural aggregates and high organic matter accumulating soil surface. The result agrees with the work of Elias [57] and Chimdi et al. [80], who reported higher water holding capacity for soils with higher clay content in Nitisol profiles of some highlands of Ethiopia and Welega, western Ethiopia, respectively. The finding of this result is substantiated by Yimer et al. [81], who reported higher soil moisture content under exclosures in the grassland area than in open grazing land use in Ethiopia's central rift valley area. Besides, low soil moisture was recorded in middle topography, which may be due to soil degradation, intensive cultivation and free open grazing. 
TABLE 3: Mean values \pm SE of soil bulk density, total porosity, and soil moisture in different land use types across altitudinal gradients.

\begin{tabular}{|c|c|c|c|c|c|}
\hline \multirow{2}{*}{ Soil variables } & \multirow{2}{*}{ Land use types } & \multicolumn{3}{|c|}{ Altitudinal gradients } & \multirow[t]{2}{*}{ Average } \\
\hline & & Lower & Middle & Upper & \\
\hline \multirow{4}{*}{ Bulk density $\left(\mathrm{g} \mathrm{cm}^{-3}\right)$} & Barren land & - & $1.34 \pm 0.03$ & $1.40 \pm 0.03$ & $1.37^{\mathrm{a}} \pm 0.10$ \\
\hline & Cultivated land & $1.09 \pm 0.03$ & $1.21 \pm 0.03$ & $1.32 \pm 0.03$ & $1.21^{\mathrm{b}} \pm 0.10$ \\
\hline & Grassland & $0.98 \pm 0.03$ & $1.25 \pm 0.03$ & $1.19 \pm 0.03$ & $1.14^{\mathrm{c}} \pm 0.10$ \\
\hline & Plantation forest & - & $1.15 \pm 0.03$ & $1.22 \pm 0.03$ & $1.19^{b c} \pm 0.10$ \\
\hline Average & & $1.04^{\mathrm{b}} \pm 0.03$ & $1.24^{\mathrm{a}} \pm 0.03$ & $1.28^{\mathrm{a}} \pm 0.03$ & $1.23 \pm 0.10$ \\
\hline \multirow{4}{*}{ Total porosity (\%) } & Barren land & - & $49.68 \pm 1.05$ & $47.44 \pm 1.05$ & $48.56^{\mathrm{C}} \pm 1.05$ \\
\hline & Cultivated land & $58.87 \pm 1.05$ & $54.50 \pm 1.05$ & $50.28 \pm 1.05$ & $54.55^{\mathrm{b}} \pm 1.05$ \\
\hline & Grassland & $63.06 \pm 1.05$ & $52.95 \pm 1.05$ & $55.24 \pm 1.05$ & $57.08^{\mathrm{a}} \pm 1.05$ \\
\hline & Plantation forest & - & $56.69 \pm 1.05$ & $54.20 \pm 1.05$ & $55.45^{\mathrm{ab}} \pm 1.05$ \\
\hline Average & & $60.96^{\mathrm{a}} \pm 1.05$ & $53.46^{\mathrm{b}} \pm 1.05$ & $51.79^{\mathrm{b}} \pm 1.05$ & $53.91 \pm 1.05$ \\
\hline \multirow{4}{*}{ Soil moisture (\%) } & Barren land & - & $9.08 \pm 1.31$ & $9.87 \pm 1.31$ & $9.47^{\mathrm{b}} \pm 1.31$ \\
\hline & Cultivated land & $18.98 \pm 1.31$ & $13.66 \pm 1.31$ & $14.30 \pm 1.31$ & $15.65^{\mathrm{a}} \pm 1.31$ \\
\hline & Grassland & $22.62 \pm 1.31$ & $14.04 \pm 1.31$ & $16.37 \pm 1.31$ & $17.67^{\mathrm{a}} \pm 1.31$ \\
\hline & Plantation forest & - & $15.12 \pm 1.31$ & $15.55 \pm 1.31$ & $15.34^{\mathrm{a}} \pm 1.31$ \\
\hline Average & & $20.80^{\mathrm{a}} \pm 1.31$ & $12.98^{\mathrm{b}} \pm 1.31$ & $14.02^{\mathrm{b}} \pm 1.31$ & $14.53 \pm 1.31$ \\
\hline
\end{tabular}

Overall means within columns and rows followed by the same superscript letter(s) are not significantly different $(p<0.05)$ as influenced by land use and altitude based on Duncan's test. Values shown are means \pm standard error $(n=3)$.

Moreover, the post hoc test (Bonferroni) results showed that $\mathrm{BD}, \mathrm{TP}$, and soil moisture were found significantly $(p<0.05$, $p<0.01$, and $p<0.001$, respectively) varied between the different land use types and topographic positions (Table 5).

\subsection{The Effects of Land Use Type and Altitudinal Gradient on Selected Soil Chemical Properties}

3.3.1. Soil Reaction (Soil pH) and Electric Conductivity (EC). The overall mean soil $\mathrm{pH}-\mathrm{H}_{2} \mathrm{O}$ ranged from $6.48 \pm 0.08$ to $7.31 \pm 0.08$ (Table 6), which is rated as moderately acidic to neutral (Table 4), according to Karltun et al. [56]. But, there was marked variation among land use types across altitudinal gradients (Table 6). The mean EC is $0.20 \pm 0.01 \mathrm{mS} \mathrm{cm}^{-1}$ with the highest mean value of $0.37 \pm 0.01 \mathrm{~cm}^{-1}$ at grassland, rated as salt free. Comparatively higher soil $\mathrm{pH}$ was measured in grassland across all topographic gradients (Table 6), which might be due to the increase in surface soil organic matter, which traps base cations. Additionally, the accumulation of bases that are supposed to be moved laterally by erosion and sediment on grassland and cattle dung wastes deposited on grass fields. The finding was in agreement with Mekuria et al. [75] who justified organic matter accumulation might reduce soil erosion resulting in higher soluble base cations $\left(\mathrm{Ca}^{2+}\right.$ and $\mathrm{Mg}^{2+}$ ), which reduce $\mathrm{H}^{+}$responsible for acidity, which, in turn, increases soil $\mathrm{pH}$ in the grassland soils. Tang et al. [82] reported a similar higher $\mathrm{pH}$ result $(7.11 \pm 0.27)$ of grassland than other land uses in the Horqin Sandy Land of China. On the other hand, plantation forests measured the lowest soil $\mathrm{pH}$ compared to other land use. The low $\mathrm{pH}$ scale in plantation forests may be ascribed to the effect of allelopathy associated with Eucalyptus trees and intense leaching of basic cations. Hence, chemicals released from the leaves and roots of Eucalyptus trees slow down the litter's breakdown by affecting microbial activity, reducing the soil nutrients concentration, mainly base cations. In line with this result, Zerga [83] reported the case with allelopathy chemical released from
Eucalyptus; Yerima and Van Ranst [84] also added reduced activity of litter decomposing microbial at low $\mathrm{pH}$. Furthermore, low $\mathrm{pH}$ at the cultivated land in lower elevation may be associated to the intensive tillage frequency which stimulates leaching of base cations, the use of chemical fertilizers, and weedicides which contain high amounts of cations which neutralize the negative charges and due to the depletion of basic cations through crop harvesting. Supporting our result, Mohammed et al. [85], Mohammed [86], and Yihenew et al. [3] reported that the lowest value of $\mathrm{pH}$ under the cultivated land is due to the depletion of basic cations in crop harvest and leached streams in runoff generated from accelerated erosion. Similarly, Bore and Bedadi [65] also found the lower soil reaction under the cultivated land compared to the adjacent forest and grazing land in southern Ethiopia.

The lower and upper elevations recorded the highest mean soil $\mathrm{pH}$ value in the study watershed, which might be attributed to the accumulation of bases due to partial exclosures management practice at both landscape positions (Table 6). However, the lowest soil pH at the middle elevation is due to soil erosion, intensive cultivation, and free open grazing pressure. The overall $\mathrm{pH}$ value of the studied watershed is almost within the neutral range category, according to EthioSIS [56], for critical levels used for classifying soil fertility analysis for Ethiopian soils. The criteria used by the CASCAPE (CASCAPE: Capacity building for Scaling up of Evidence-based best Practices for increased Agricultural Production in Ethiopia) project [46], which is very detailed in comparison, show that the overall soil $\mathrm{pH}$ range of the study watershed is moderately acidic to neutral.

Soil EC is affected by cropping, irrigation, land use, fertilizer, manure, and compost. However, in this study, soil EC was found salt free according to EthioSIS [56] ratings and ranged from $0.16-0.47,0.12-0.28$, and $0.08-0.36 \mathrm{mS} \mathrm{cm}^{-1}$ in lower, middle, and upper topographies, respectively. The highest EC among different land use types were detected 
TABLE 4: Critical levels used for classifying soil fertility analysis results in Ethiopia [56].

\begin{tabular}{|c|c|c|}
\hline Soil parameter & Status & Critical level adopted by EthioSIS \\
\hline Soil pH (water) & $\begin{array}{c}\text { Strongly acidic } \\
\text { Moderately acidic } \\
\text { Neutral } \\
\text { Moderately alkaline } \\
\text { Strongly alkaline }\end{array}$ & $\begin{array}{c}<5.5 \\
5.6-6.5 \\
6.6-7.3 \\
7.3-8.4 \\
>8.4\end{array}$ \\
\hline Phosphorus (mg/kg) & $\begin{array}{l}\text { Very low } \\
\text { Low } \\
\text { Optimum } \\
\text { High } \\
\text { Very high }\end{array}$ & $\begin{array}{c}0-15 \\
15-30 \\
30-80 \\
80-150 \\
>150\end{array}$ \\
\hline Potassium (mg/kg) & $\begin{array}{l}\text { Very low } \\
\text { Low } \\
\text { Optimum } \\
\text { High } \\
\text { Very high }\end{array}$ & $\begin{array}{c}<90 \\
90-190 \\
190-600 \\
600-900 \\
>900\end{array}$ \\
\hline Calcium saturation percentage & $\begin{array}{l}\text { Very low } \\
\text { Low } \\
\text { Optimum } \\
\text { High } \\
\text { Very high }\end{array}$ & $\begin{array}{c}<30 \\
30-50 \\
50-70 \\
70-80 \\
>80 \\
\end{array}$ \\
\hline Magnesium saturation percentage & $\begin{array}{l}\text { Very low } \\
\text { Low } \\
\text { Optimum } \\
\text { High } \\
\text { Very high }\end{array}$ & $\begin{array}{c}<8 \\
8-10 \\
10-18 \\
18-25 \\
>25\end{array}$ \\
\hline Exchangeable sodium percentage (ESP) & $\begin{array}{l}\text { Very low } \\
\text { Low } \\
\text { Optimum } \\
\text { High } \\
\text { Very high }\end{array}$ & $\begin{array}{c}<0.5 \\
0.5-1.0 \\
1.0-3.5 \\
3.5-5 \\
>5\end{array}$ \\
\hline Sulfur $(\mathrm{mg} / \mathrm{kg})$ & $\begin{array}{l}\text { Very low } \\
\text { Low } \\
\text { Optimum } \\
\text { High } \\
\text { Very high } \\
\end{array}$ & $\begin{array}{c}<10 \\
10-20 \\
20-80 \\
80-100 \\
>100 \\
\end{array}$ \\
\hline Zinc $(\mathrm{mg} / \mathrm{kg})$ & $\begin{array}{l}\text { Very low } \\
\text { Low } \\
\text { Optimum } \\
\text { High } \\
\text { Very high }\end{array}$ & $\begin{array}{c}<1 \\
1-1.5 \\
1.5-10 \\
10-20 \\
>20\end{array}$ \\
\hline Iron $(\mathrm{mg} / \mathrm{kg})$ & $\begin{array}{l}\text { Very low } \\
\text { Low } \\
\text { Optimum } \\
\text { High } \\
\text { Very high }\end{array}$ & $\begin{array}{c}<60 \\
60-80 \\
80-300 \\
300-400 \\
>400\end{array}$ \\
\hline Manganese activity index (MAI) & Low & $<25$ \\
\hline Copper (mg/kg) & $\begin{array}{l}\text { Very low } \\
\text { Low } \\
\text { Optimum } \\
\text { High } \\
\text { Very high }\end{array}$ & $\begin{array}{c}<0.5 \\
0.5-0.9 \\
1-20 \\
20-30 \\
>30\end{array}$ \\
\hline Boron $(\mathrm{mg} / \mathrm{kg})$ & $\begin{array}{l}\text { Very low } \\
\text { Low } \\
\text { Optimum } \\
\text { High } \\
\text { Very high }\end{array}$ & $\begin{array}{c}<0.5 \\
0.5-0.8 \\
0.8-2.0 \\
2.0-4.0 \\
>4.0\end{array}$ \\
\hline
\end{tabular}


TABLE 4: Continued.

\begin{tabular}{|c|c|c|}
\hline Soil parameter & Status & Critical level adopted by EthioSIS \\
\hline \multirow{5}{*}{ Total nitrogen (\%) } & Very low & $<0.1$ \\
\hline & Low & $0.1-0.15$ \\
\hline & Optimum & $0.15-0.3$ \\
\hline & High & $0.3-0.5$ \\
\hline & Very high & $>0.5$ \\
\hline \multirow{5}{*}{$\mathrm{OM}(\%)$} & Very low & $<2.0$ \\
\hline & Low & $2.0-3.0$ \\
\hline & Optimum & $3.0-7.0$ \\
\hline & High & $7.0-8.0$ \\
\hline & Very high & $>8.0$ \\
\hline \multirow{5}{*}{$\mathrm{EC}\left(\mathrm{mS} \mathrm{cm}^{-1}\right)$} & Salt free & $<2$ \\
\hline & Very slightly saline & $2-4$ \\
\hline & Slightly saline & $4-8$ \\
\hline & Moderately saline & $8-16$ \\
\hline & Strongly saline & $>16$ \\
\hline
\end{tabular}

TABLE 5: Results of post hoc multiple comparison (Bonferroni test; $p<0.05$ ) for soil physicochemical properties with a significant difference by land use type and altitudinal gradient.

\begin{tabular}{|c|c|c|c|c|}
\hline Soil variables & $\begin{array}{c}\text { Land use type } \\
\text { Significantly contrasted land use } \\
\text { types }\end{array}$ & $\mathrm{MD} \pm \mathrm{SE}$ & $\begin{array}{c}\text { Altitudinal gradient } \\
\text { Significantly contrasted altitudinal } \\
\text { gradients }\end{array}$ & $\mathrm{MD} \pm \mathrm{SE}$ \\
\hline Sand (\%) & $\begin{array}{l}\text { Barren land and cultivated land } \\
\text { Barren land and grassland } \\
\text { Barren land and plantation forest }\end{array}$ & $\begin{array}{l}13.30 \pm 1.63^{* * *} \\
14.28 \pm 1.63^{* * *} \\
12.61 \pm 1.78^{* * *} \\
\end{array}$ & $\begin{array}{c}\text { Middle and lower } \\
\text { Upper and lower } \\
-\end{array}$ & $\begin{array}{c}10.21 \pm 1.54^{* * *} \\
11.07 \pm 1.54^{* * *} \\
- \\
\end{array}$ \\
\hline Silt (\%) & Cultivated land and barren land & $7.91 \pm 1.94^{* *}$ & Lower and upper & $5.39 \pm 1.84^{*}$ \\
\hline Clay (\%) & $\begin{array}{c}\text { Grassland and barren land } \\
\text { Grassland and cultivated land } \\
\text { Plantation forest and barren land }\end{array}$ & $\begin{array}{c}11.09 \pm 2.09^{* * *} \\
5.70 \pm 1.87^{*} \\
7.60 \pm 2.29^{*} \\
\end{array}$ & $\begin{array}{c}\text { Lower and middle } \\
\text { Lower and upper } \\
-\end{array}$ & $\begin{array}{c}6.65 \pm 1.98^{* *} \\
5.68 \pm 1.98^{*} \\
- \\
\end{array}$ \\
\hline Soil moisture (\%) & $\begin{array}{l}\text { Cultivated land and barren land } \\
\text { Grassland and barren land } \\
\text { Plantation forest and barren land }\end{array}$ & $\begin{array}{c}6.17 \pm 1 . .20^{* * *} \\
8.20 \pm 1.20^{* * *} \\
5.86 \pm 1.31^{* *} \\
\end{array}$ & $\begin{array}{c}\text { Lower and middle } \\
\text { Lower and upper } \\
-\end{array}$ & $\begin{array}{c}7.82 \pm 1.14^{* * *} \\
6.77 \pm 1.14^{* * *} \\
-\end{array}$ \\
\hline Bulk density $\left(\mathrm{g} \mathrm{cm}^{-3}\right)$ & $\begin{array}{l}\text { Barren land and cultivated land } \\
\text { Barren land and grassland } \\
\text { Barren land and plantation forest } \\
\text { Cultivated land and grassland }\end{array}$ & $\begin{array}{c}0.16 \pm 0.03^{* * *} \\
0.23 \pm 0.03^{* * *} \\
0.18 \pm 0.03^{* * *} \\
0.07 \pm 0.02^{*}\end{array}$ & $\begin{array}{c}\text { Middle and lower } \\
\text { Upper and lower } \\
- \\
-\end{array}$ & $\begin{array}{c}0.20 \pm 0.02^{* * *} \\
0.24 \pm 0.02^{* * *} \\
- \\
-\end{array}$ \\
\hline Total porosity (\%) & $\begin{array}{l}\text { Cultivated land and barren land } \\
\text { Grassland and barren land } \\
\text { Grassland and cultivated land } \\
\text { Plantation forest and barren land }\end{array}$ & $\begin{array}{c}5.99 \pm 0.96^{* * *} \\
8.52 \pm 0.96^{* * *} \\
2.53 \pm 0.86^{*} \\
6.89 \pm 1.05^{* * *} \\
\end{array}$ & $\begin{array}{c}\text { Lower and middle } \\
\text { Lower and upper } \\
- \\
-\end{array}$ & $\begin{array}{c}7.51 \pm 0.91^{* * *} \\
9.18 \pm 0.91^{* * *} \\
- \\
-\end{array}$ \\
\hline pH-water $(1: 2.5)$ & $\begin{array}{c}\text { Barren land and plantation forest } \\
\text { Cultivated land and plantation } \\
\text { forest } \\
\text { Grassland and barren land } \\
\text { Grassland and cultivated land } \\
\text { Grassland and plantation forest }\end{array}$ & $\begin{array}{c}0.60 \pm 0.08^{* * *} \\
0.53 \pm 0.07^{* * *} \\
0.24 \pm 0.07^{*} \\
0.30 \pm 0.06^{* *} \\
0.83 \pm 0.07^{* * *} \\
\end{array}$ & $\begin{array}{l}\text { Lower and middle } \\
\text { Upper and middle } \\
\text { - } \\
\text { - } \\
\end{array}$ & $\begin{aligned} 0.28 & \pm 0.07^{* *} \\
0.27 & \pm 0.05^{* * *} \\
& - \\
& - \\
& -\end{aligned}$ \\
\hline $\begin{array}{l}\text { Electrical conductivity } \\
\left(\mathrm{mScm}^{-1}\right)\end{array}$ & $\begin{array}{c}\text { Cultivated land and barren land } \\
\text { Grassland and barren land } \\
\text { Grassland and cultivated land } \\
\text { Grassland and plantation forest } \\
\text { Plantation forest and barren land } \\
\text { Plantation forest and cultivated } \\
\text { land }\end{array}$ & $\begin{array}{c}0.04 \pm 0.01^{* *} \\
0.27 \pm 0.01^{* * *} \\
0.23 \pm 0.01^{* * *} \\
0.18 \pm 0.01^{* * *} \\
0.09 \pm 0.01^{* * *} \\
0.05 \pm 0.01^{* * *}\end{array}$ & $\begin{array}{l}\text { Lower and middle } \\
\text { Lower and upper } \\
\qquad- \\
- \\
- \\
-\end{array}$ & $\begin{array}{c}0.13 \pm 0.01^{* * *} \\
0.13 \pm 0.01^{* * *} \\
- \\
- \\
- \\
-\end{array}$ \\
\hline
\end{tabular}


TABLE 5: Continued.

\begin{tabular}{|c|c|c|c|c|}
\hline Soil variables & $\begin{array}{c}\text { Land use type } \\
\text { Significantly contrasted land use } \\
\text { types }\end{array}$ & $\mathrm{MD} \pm \mathrm{SE}$ & $\begin{array}{c}\text { Altitudinal gradient } \\
\text { Significantly contrasted altitudinal } \\
\text { gradients }\end{array}$ & $\mathrm{MD} \pm \mathrm{SE}$ \\
\hline \multirow{5}{*}{$\operatorname{SOM}(\%)$} & Cultivated land and barren land & $1.10 \pm 0.09^{* * *}$ & Lower and middle & $1.46 \pm 0.08^{* * *}$ \\
\hline & Grassland and barren land & $1.74 \pm 0.09^{* * *}$ & Lower and upper & $1.60 \pm 0.08^{* * *}$ \\
\hline & Grassland and cultivated land & $0.64 \pm 0.08^{* * *}$ & - & - \\
\hline & Grassland and plantation forest & $0.86 \pm 0.09^{* * *}$ & - & - \\
\hline & Plantation forest and barren land & $0.87 \pm 0.10^{* * *}$ & - & - \\
\hline \multirow{5}{*}{ SOC (\%) } & Cultivated land and barren land & $0.64 \pm 0.05^{* * *}$ & Lower and middle & $0.84 \pm 0.05^{* * *}$ \\
\hline & Grassland and barren land & $1.01 \pm 0.05^{* * *}$ & Lower and upper & $0.93 \pm 0.05^{* * *}$ \\
\hline & Grassland and cultivated land & $0.37 \pm 0.05^{* * *}$ & - & - \\
\hline & Grassland and plantation forest & $0.50 \pm 0.05^{* * *}$ & - & - \\
\hline & Plantation forest and barren land & $0.51 \pm 0.06^{* * *}$ & - & - \\
\hline \multirow{2}{*}{$\mathrm{TN}(\%)$} & Cultivated land and barren land & $0.05 \pm 0.01^{* *}$ & Lower and middle & $0.04 \pm 0.01^{* *}$ \\
\hline & Grassland and barren land & $0.04 \pm 0.01^{* *}$ & Lower and upper & $0.04 \pm 0.01^{* *}$ \\
\hline \multirow{5}{*}{$C: N$} & Cultivated land and barren land & $2.01 \pm 0.61^{*}$ & Lower and middle & $2.03 \pm 0.58^{* *}$ \\
\hline & Grassland and barren land & $4.75 \pm 0.61^{* * *}$ & Lower and upper & $3.59 \pm 0.58^{* * *}$ \\
\hline & Grassland and cultivated land & $2.74 \pm 0.55^{* * *}$ & Middle and upper & $1.57 \pm 0.47^{*}$ \\
\hline & Grassland and plantation forest & $2.15 \pm 0.61^{*}$ & - & - \\
\hline & Plantation forest and barren land & $2.60 \pm 0.67^{* *}$ & - & - \\
\hline $\mathrm{P}_{\mathrm{av}}\left(\mathrm{mg} \mathrm{kg}^{-1}\right)$ & Barren land and plantation forest & $10.22 \pm 3.00^{*}$ & Upper and middle & $9.27 \pm 2.12^{* *}$ \\
\hline
\end{tabular}

SOM: soil organic matter, SOC: soil organic carbon, TN: total nitrogen, C:N: carbon-to-nitrogen ratio, $\mathrm{P}_{\text {av }}$ available phosphorus, ${ }^{*},{ }^{* *}$, and ${ }^{* * *}$ designate significance at $p<0.05,0.01$, and 0.001 , respectively, $\mathrm{MD}$ : mean difference, $\mathrm{SE}=$ standard error.

TABLE 6: Effects of land use types and altitudinal gradients on soil $\mathrm{pH}\left(\mathrm{H}_{2} \mathrm{O}\right)$ and EC.

\begin{tabular}{lccccc}
\hline \multirow{2}{*}{ Soil variables } & Land use types & \multicolumn{3}{c}{ Altitudinal gradients } & Average \\
& & Lower & Middle & Upper & $7.07^{\mathbf{b}} \pm 0.08$ \\
& Barren land & - & $6.84 \pm 0.08$ & $7.30 \pm 0.08$ & $7.01^{\mathbf{b}} \pm 0.08$ \\
$\mathrm{pH}$ (water) & Cultivated land & $7.10 \pm 0.08$ & $6.99 \pm 0.08$ & $6.93 \pm 0.08$ & $7.31^{\mathbf{a}} \pm 0.08$ \\
& Grassland & $7.14 \pm 0.08$ & $7.24 \pm 0.08$ & $7.54 \pm 0.08$ & $6.48^{\mathbf{c}} \pm 0.08$ \\
Average & Plantation forest & - & $6.29 \pm 0.08$ & $6.66 \pm 0.08$ & $\mathbf{6 . 9 7}^{\mathbf{b}} \pm 0.08$ \\
\hline & & $7.12^{\mathbf{a}} \pm 0.08$ & $0.12 \pm 0.01$ & $0.08 \pm 0.01$ & $0.10^{\mathbf{d}} \pm 0.01$ \\
EC $\left(\mathrm{mS} \mathrm{cm}^{-1}\right)$ & Barren land & - & $0.13 \pm 0.01$ & $0.12 \pm 0.01$ & $0.14^{\mathbf{c}} \pm 0.01$ \\
& Cultivated land & $0.16 \pm 0.01$ & $0.28 \pm 0.01$ & $0.36 \pm 0.0$ & $0.37^{\mathbf{a}} \pm 0.01$ \\
Average & Grassland & $0.47 \pm 0.01$ & $0.20 \pm 0.01$ & $0.18 \pm 0.01$ & $0.19^{\mathbf{b}} \pm 0.01$ \\
\hline
\end{tabular}

Overall means within columns and rows followed by the same superscript letter(s) are not significantly different $(p<0.05)$ as influenced by land use and altitude based on Duncan's test. Values shown are means \pm standard error $(n=3)$.

under GL at all topographies, followed by PF of both upstream positions (Table 6), whereas the lowest EC was obtained under BL of the upstream, followed by CL of the downstream watershed (Table 6). Contrary to our result, Kizilkaya and Dengiz [87] reported that changing a forest land to CL increased EC values due to high application rates of chemical fertilizers. Since EC represents the soil soluble salt component, the use of basic chemical fertilizers such as ammonium phosphate and urea under farmland can lead to higher EC values above normal (EC $>0.15 \mathrm{mS} \mathrm{cm}^{-1}$ ), but this did not happen in our study area may be due to runoff and leaching lose. Thus, farmers must avoid complete reliance on chemical inputs and should shift to rely more on organic fertilization to keep EC $<0.15$ in their soils. Since the obtained EC value is less than one, the possibility of forming a salinity problem in the study watershed is implausible.

3.3.2. Soil Organic Matter (SOM), Soil Organic Carbon (SOC), Total $N(T N)$, and $C: N$ Ratio. The SOM, SOC, TN, and $\mathrm{C}: \mathrm{N}$ ratio differed across altitudes and land use types and decreased as elevation increases in Ayiba watershed soils (Table 7). Based on the ratings of EthioSIS [56], the SOM of the study, watershed soil was found optimum at the lower elevation and low at middle and upper elevations, which might be ascribed to temperature decreases as elevation increases, which disfavor plants to survive at a higher altitude; hence, the accumulation of organic matter decreases. There was less SOM by about $43.98 \%$ and $48.19 \%$ across 
TABLE 7: Mean values \pm SE of soil organic matter (SOM), soil organic carbon (SOC), total nitrogen (TN), and carbon-to-nitrogen ratio $(\mathrm{C}: \mathrm{N})$ in different land use types across altitudinal gradients.

\begin{tabular}{|c|c|c|c|c|c|}
\hline \multirow{2}{*}{ Soil variables } & \multirow{2}{*}{ Land use types } & \multicolumn{3}{|c|}{ Altitudinal gradients } & \multirow{2}{*}{ Average } \\
\hline & & Lower & Middle & Upper & \\
\hline \multirow{4}{*}{ SOM (\%) } & Barren land & - & $1.18 \pm 0.10$ & $0.96 \pm 0.10$ & $1.07^{\mathrm{d}} \pm 0.10$ \\
\hline & Cultivated land & $2.40 \pm 0.10$ & $1.96 \pm 0.10$ & $1.57 \pm 0.10$ & $1.98^{\mathrm{c}} \pm 0.10$ \\
\hline & Grassland & $4.24 \pm 0.10$ & $1.98 \pm 0.10$ & $2.22 \pm 0.10$ & $2.81^{\mathrm{a}} \pm 0.10$ \\
\hline & Plantation forest & - & $2.32 \pm 0.10$ & $2.13 \pm 0.10$ & $2.23^{\mathrm{b}} \pm 0.10$ \\
\hline Average & & $3.32^{\mathrm{a}} \pm 0.10$ & $1.86^{\mathrm{b}} \pm 0.10$ & $1.72^{\mathrm{b}} \pm 0.10$ & $2.02 \pm 0.10$ \\
\hline \multirow{4}{*}{ SOC (\%) } & Barren land & - & $0.69 \pm 0.06$ & $0.56 \pm 0.06$ & $0.62^{\mathrm{d}} \pm 0.06$ \\
\hline & Cultivated land & $1.39 \pm 0.06$ & $1.14 \pm 0.06$ & $0.91 \pm 0.06$ & $1.15^{\mathrm{c}} \pm 0.06$ \\
\hline & Grassland & $2.46 \pm 0.06$ & $1.15 \pm 0.06$ & $1.29 \pm 0.06$ & $1.63^{\mathrm{a}} \pm 0.06$ \\
\hline & Plantation forest & - & $1.34 \pm 0.06$ & $1.24 \pm 0.06$ & $1.29^{\mathrm{b}} \pm 0.06$ \\
\hline Average & & $1.93^{\mathrm{a}} \pm 0.06$ & $1.08^{\mathrm{b}} \pm 0.06$ & $1.00^{\mathrm{b}} \pm 0.06$ & $1.17 \pm 0.06$ \\
\hline \multirow{4}{*}{ TN (\%) } & Barren land & - & $0.10 \pm 0.01$ & $0.10 \pm 0.01$ & $0.10^{c} \pm 0.01$ \\
\hline & Cultivated land & $0.17 \pm 0.01$ & $0.17 \pm 0.01$ & $0.17 \pm 0.01$ & $0.17^{\mathrm{b}} \pm 0.01$ \\
\hline & Grassland & $0.23 \pm 0.01$ & $0.14 \pm 0.01$ & $0.20 \pm 0.01$ & $0.19^{\mathrm{ab}} \pm 0.01$ \\
\hline & Plantation forest & - & $0.20 \pm 0.01$ & $0.19 \pm 0.01$ & $0.20^{\mathrm{a}} \pm 0.01$ \\
\hline Average & & $0.20^{\mathrm{a}} \pm 0.01$ & $0.15^{\mathrm{b}} \pm 0.01$ & $0.16^{\mathrm{b}} \pm 0.01$ & $0.17 \pm 0.01$ \\
\hline \multirow{4}{*}{$C: N$} & Barren land & - & $6.90 \pm 0.70$ & $5.85 \pm 0.70$ & $6.38^{\mathrm{b}} \pm 0.70$ \\
\hline & Cultivated land & $8.65 \pm 0.70$ & $6.78 \pm 0.70$ & $5.51 \pm 0.70$ & $6.98^{\mathrm{b}} \pm 0.70$ \\
\hline & Grassland & $11.08 \pm 0.70$ & $8.18 \pm 0.70$ & $6.57 \pm 0.70$ & $8.61^{a} \pm 0.70$ \\
\hline & Plantation forest & - & $6.73 \pm 0.70$ & $6.70 \pm 0.70$ & $6.71^{b} \pm 0.70$ \\
\hline Average & & $9.86^{\mathrm{a}} \pm 0.70$ & $7.15^{\mathrm{b}} \pm 0.70$ & $6.16^{\mathrm{b}} \pm 0.70$ & $7.17 \pm 0.70$ \\
\hline
\end{tabular}

Overall means within columns and rows followed by the same letter(s) are not significantly different $(p<0.05)$ as influenced by land use and altitude based on Duncan's test. Values shown are means \pm standard error $(n=3)$.

landscape positions, assuming the lower altitude as the base for comparison. Similarly, Shazia et al. [88] had reported high organic matter $(2.89 \pm 0.48$ at 1660 m.a.s.l) at a lower elevation than at higher elevation $(1.82 \pm 0.57$ at 2133 m.a.s.l.) in Sra Ghurgai (Takatu mountain range) Quetta, Balochistan, and many other studies also discovered the same trend related to elevation with organic carbon accumulation $[89,90]$.

Moreover, GL recorded the highest SOC (2.46\%) in the lower landscape position, and BL recorded the lowest SOC $(0.56 \%)$ in the upper landscape position (Table 7). Based on the ratings of Hazelton and Murphy [76] $(<1.0,1.0-1.71$, $1.72-3.0,3.1-4.29$, and $>4.3$ leveled as very low, low, medium, high, and very high, respectively), the SOC of the study watershed soil was found from low to medium level across altitudinal gradients and very low to low level among land use types (Table 7). The higher SOM and SOC under GL (at lower and upper elevation) in this study are attributable to the partial exclosures practice, reduced grazing pressure and allowed regeneration of native vegetation, and increased SOC in the topsoil. Particularly, deforestation of native forests for crop production to feed the increasing population in mountainous areas dramatically increases the soil's vulnerability for rainfall-driven erosion. Following the escalating erosion process, the organic humus and fine particles are transported down the slope from the upper streams with runoff water and accumulated at the lower stream. Therefore, this destructive ecosystem degradation increases SOM and SOC at a lower landscape position.

Recently, the reduction of soil quality and crop productivity has become severe in some Ethiopian highland regions, indicating the degradation of SOM and SOC, including the study area. Moreover, land use changes and subsequent tillage practices resulted in significant decreases in organic matter. Thus, cultivated soils generally have low organic matter content than native ecosystems since cultivation increases the soil's aeration, enhancing SOM decomposition. Besides, complete crop harvest reduces the SOM in CL. The finding of this research work is in accordance with the work of Elias [57] and Gebreselassie et al. [61], who reported a higher mean value of SOC on a lower slope than the upper. Many other studies conducted in a mountainous area also reported that the cultivation of steep and fragile soils, limited recycling of dung and crop residues, deforestation, and overgrazing [91] are driving agents. Elias [4] and van Beek et al. [92] also reported poor soil management, soil erosion, leaching of nutrients, and organic matter depletion as driving factors for poor soil productivity in the Ethiopian highlands. Moreover, other than Ethiopia, Nsalambi [93] also reported similar results revealing total carbon concentrations, and its fractions were all higher at waterway (depression) and lowest at the summit position at Busby forest in central Missouri. Jendoubi et al. [94] also reported a marked decline in SOC with increased slopes under different land uses and topography in the Mediterranean landscape. Majule [40] also reported that cleaning the natural forest in most upper zones for cultivation has contributed significantly to SOC and N's reduced soil level.

Given the independent effect of land use, we found the overall means SOM and SOC content was decreasing as $\mathrm{GL}>\mathrm{PF}>\mathrm{CL}>\mathrm{BL}$ (Table 7) in this study. Explicitly, the estimated mean SOM and SOC were found higher in GL in all landscape positions except in the middle ones, where the $\mathrm{PF}$ was found high. The barren land at upper and middle and 
CL at lower topographies recorded low SOM and SOC in this study. Our finding agrees with the work of Girmay and Singh [10], who reported higher SOC in exclosures, GL, and plantation areas than CL in Mileba and Gum Slassie areas, northern Ethiopia. Delelegn et al. [95] also reported higher SOC in GL than cropland in Ambo Ber district, Ethiopia. SOC was found low compared to croplands, forestlands, and grazing lands [96]. According to Karltun et al. [56], SOC's optimum baseline limit is $2 \%$. SOC content in all land use types across topography except GL $(2.46 \%)$ at a lower elevation was found below the baseline limit. Besides, Gurmu [97] highlighted that lower SOC could result in poor aggregate stability and, thus, aggravate soil degradation. Therefore, a sustained level of SOC is critically important for ecosystem health.

The highest TN content was observed in the GL $(0.23 \%)$ at low altitude, followed by GL $(0.20 \%)$ at upper and PF $(0.20 \%)$ at middle altitudes. The average values of TN in the study watershed ranged from the highest $0.2 \%$ in the PF lands to the lowest $0.10 \%$ in $\mathrm{BL}$ among land use types and from the highest $0.20 \%$ at a low altitude to the lowest $0.15 \%$ at middle altitude across topography (Table 7). The mean TN content was inconsistent across altitude. The soils are found low to optimum in soil TN as per the EthioSIS ratings [56] with average mean values of $0.17 \%$. The very low value of soil TN observed under BL and CL may be attributed to deforestation, soil erosion, continuous cultivation, plant uptake, and volatilization. Correspondingly, the low carbon input obtained from the subsistence agricultural crop production system could not compensate $\mathrm{N}$ losses by OM mineralization, leaching, and denitrification. Other studies similarly reported that deforestation and landscape fragmentation are the two most important factors affecting natural landscape settings, reducing the ecosystem services such as SOC and TN regulation accumulation $[5,98,99]$. On the other hand, TN's relatively high mean value under PF lands could be attributed to the good microclimate conditions, which might have moderated the soil temperature and decreased TN loss by volatilization because the vegetation cover enriched the SOM. According to Walworth [100], the OM in the soil contributes roughly $95 \%$ for soil TN contents. The result is inconsistent with Ethiopia's observations $[67,101]$. There was an increase in soil TN contents of rehabilitated degraded bare land soil.

Carbon-to-Nitrogen $(\mathrm{C}: \mathrm{N})$ ratio is important because it directly impacts residue decomposition and nitrogen cycling in our soils with an ideal microbial diet of 24:1 (https:// advancecovercrops.com/resources-advanced-cover-crops/ carbon-nitrogen-ratio/). The $\mathrm{C}: \mathrm{N}$ ratio indicates the dynamic balance of SOC and TN contents in a substance [79]. It is a good indicator of the degree of decomposition and mineralization rate of SOC and the cycle of carbon and nitrogen in the ecological system and good indicator of the quality of the organic matter held in the soil $[102,103]$. The $\mathrm{C}: \mathrm{N}$ ratios of the study watershed soils were significantly $(p<0.001)$ affected by land use types and altitude (Table 2$)$. The mean $\mathrm{C}: \mathrm{N}$ ratio of the soils also varied between 6.38 and 8.61 among land use types and between 6.16 and 9.86 across altitude (Table 7 ). There are six to eight carbon units among land use types and six to nine units of carbon across altitude for each nitrogen unit in the substance. In this study, the $C$ : $\mathrm{N}$ ratio showed a decreasing trend as altitude increases. GL at low altitude recorded the highest $\mathrm{C}: \mathrm{N}$ ratio, and $\mathrm{CL}$ at upper altitude recorded the lowest $\mathrm{C}: \mathrm{N}$ ratio. The present finding is in agreement with the work of Gebreslassie and Ayanna [104], who reported the highest values of the $C: N$ ratio under grazing land in northwestern Ethiopian soils. Researchers reported that the $\mathrm{C}: \mathrm{N}$ ratio is affected by land use due to competing interests of space for different purposes such as crop production, livestock, and settlement $[99,102]$. Severe depletion of organic matter and continuous mining of soil $\mathrm{N}$ and $\mathrm{S}$ in the Ethiopian highlands is accredited to the practice of complete removal of crop residues as cattle feed and dung burning for household energy, as well as low levels of $\mathrm{N}$ fertilizer application $\left(46 \mathrm{~kg} \mathrm{~N} \mathrm{ha}^{-1}\right)$ and no application of S fertilizer until recently [105]. Thus, the protection and management of forest and grassland fragments within the human-modified landscapes and supplying energy choice for the rural community are among the alternative options to keep the balance.

3.3.3. Available Phosphorus $\left(P_{a v}\right)$ and Exchangeable Potassium $\left(K_{\text {exch }}\right)$. ANOVA revealed that the $\mathrm{P}_{\mathrm{av}}$ values significantly differed among land use $(p<0.05)$, altitudes $(p<0.01)$, and their interactions $(p<0.05)$ (Table 2$)$, suggesting that land use types and the topographic factor of altitude exerted influence on $\mathrm{P}_{\mathrm{av}}$ concentration. The mean $\mathrm{P}_{\mathrm{av}}$ content of the study watershed soils ranges from $19.17 \mathrm{mg} \mathrm{kg}^{-1}$ to $40.20 \mathrm{mg} \mathrm{kg}^{-1}$ (Figure 6). The contents of $\mathrm{P}_{\mathrm{av}}$ in the $\mathrm{BL}$ and $\mathrm{CL}$ at upper altitude appeared to be significantly higher than other land use types in the watershed. Accordingly, comparatively highest $\left(40.2 \mathrm{mg} \mathrm{kg}^{-1}\right)$ and the lowest $\left(19.7 \mathrm{mg} \mathrm{kg}^{-1}\right) \mathrm{P}_{\mathrm{av}}$ contents were recorded under the $\mathrm{BL}$ and $\mathrm{PF}$, respectively. The data also revealed that the overall mean $\mathrm{P}_{\mathrm{av}}$ was higher $\left(35.98 \mathrm{mg} \mathrm{kg}^{-1}\right)$ in the upper altitude soils than in the middle and lower ones. Based on $\mathrm{P}_{\mathrm{av}}$ 's overall mean values, a decline of $28.08 \%, 16.54 \%$, and $14.62 \%$ in $\mathrm{PF}, \mathrm{GL}$, and $\mathrm{CL}$ is noted compared to $\mathrm{BL}$, respectively, and $25.74 \%$ and $18.37 \%$ in middle and lower topography compared to the upper topography, respectively. The low $\mathrm{P}$ fixation could explain the higher $\mathrm{P}_{\mathrm{av}}$ content in the upper topography dominated by Leptosols of young soil sources that are historically less cultivated [106] and may be due to the application of the diammonium phosphate (DAP) fertilizer on cultivated lands. Similarly, Guo et al. [107] reported lower mean contents of $\mathrm{P}_{\mathrm{av}}$ in paddy fields (lower and flat locations) than in vegetable lands (higher and steep places $)(p<0.05)$ in southwestern China. This result is also in agreement with the findings of Moges et al. [4] and Elias [108], who specified that higher mean $\mathrm{P}_{\mathrm{av}}$ in farmland compared to other land uses may be related to the application history of DAP fertilizer application. Despite substantial DAP application, the low to moderate phosphate levels, particularly in the intensive cereal system, suggest phosphate fixation [105]. Significant spatial variation of soil total phosphorus concentrations among land use types was also reported by Cheng et al. [109] in the Yingwugou 


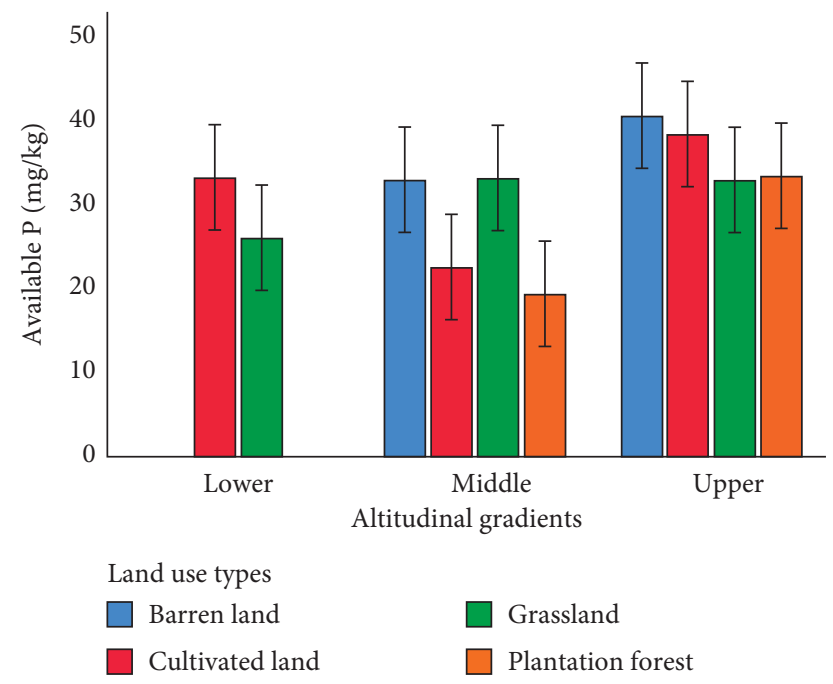

FIGURE 6: Effects of land use type and altitudinal gradient on available phosphorus at the Ayiba watershed.

\begin{tabular}{|c|c|c|c|c|c|c|c|c|c|c|c|c|c|}
\hline SOM & 1 & 0.75 & 0.39 & 0.33 & 0.33 & 0.76 & 0.68 & 0.34 & & & -0.42 & -0.81 & -0.89 \\
\hline$* * *$ & SOC & 0.75 & 0.39 & 0.33 & 0.33 & 0.76 & 0.68 & 0.34 & & & -0.42 & -0.81 & -0.89 \\
\hline$* * *$ & $* * *$ & $\mathrm{TN}$ & 0.71 & 0.7 & 0.64 & & 0.61 & 0.38 & -0.11 & -0.18 & -0.53 & -0.77 & -0.71 \\
\hline$* * *$ & $* * *$ & $* * *$ & $\mathrm{TP}$ & 0.79 & 0.68 & 0.68 & 0.68 & 0.39 & -0.07 & -0.06 & -0.56 & -0.84 & -1 \\
\hline$* * *$ & $* * *$ & $* * *$ & $* * *$ & $\mathrm{Mc}$ & 0.65 & 0.56 & 0.67 & 0.3 & -0.08 & 0.06 & -0.27 & -0.77 & -0.79 \\
\hline$* * *$ & $* * *$ & $* * *$ & $* * *$ & $* * *$ & EC & 0.51 & 0.67 & & 0.15 & 0.31 & -0.26 & -0.58 & -0.67 \\
\hline$* * *$ & $* * *$ & & $* * *$ & $* *$ & $* * *$ & C.N & 0.45 & 0.21 & 0.1 & 0.16 & -0.12 & -0.52 & -0.68 \\
\hline \multirow[t]{4}{*}{$* * *$} & $* * *$ & $* * *$ & $* * *$ & $* * *$ & $* * *$ & * & $\mathrm{CI}$ & -0.16 & 0.1 & 0.1 & -0.32 & -0.75 & -0.68 \\
\hline & & * & * & & & & & SI & -0.26 & -0.2 & -0.2 & -0.54 & -0.39 \\
\hline & & & & & & & & & K & 0.13 & & & 0.07 \\
\hline & & & & & & & & & & pH.W & 0.42 & 0.05 & 0.05 \\
\hline$*$ & * & $* *$ & $* *$ & & & & & & & * & $\mathrm{P}$ & 0.41 & 0.56 \\
\hline$* * *$ & $* * *$ & $* * *$ & $* * *$ & $* * *$ & $* * *$ & $* *$ & $* * *$ & $* *$ & & & & $\mathrm{Sa}$ & 0.34 \\
\hline$* * *$ & $* * *$ & $* * *$ & $* * *$ & $* * *$ & $* * *$ & $* *$ & $* * *$ & * & & & $* *$ & $* * *$ & $\mathrm{BD}$ \\
\hline
\end{tabular}

FiguRe 7: Pearson's correlation matrix graph for selected soil physicochemical properties of the Ayiba watershed, northern Ethiopia (note: the correlation matrices present lower left in color and $p$ values in asterisk and upper right in number (sampling depth $30 \mathrm{~cm}, n=30$ ). Positive correlations are displayed in blue, and negative correlations are in red color. Color intensity is proportional to the correlation coefficients, and ${ }^{*}, * *$, and ${ }^{* * *}$ indicate significance at $p<0.05, p<0.01$, and $p<0.001$, respectively).

watershed of the Dan River, China. According to the critical level adopted by EthioSIS [56], soil $\mathrm{P}_{\mathrm{av}}$ of the Ayiba watershed is found in low to optimum status. The post hoc multiple comparison test of $\mathrm{P}_{\mathrm{av}}$ among land use types also confirmed that $\mathrm{BL}$ had higher $\mathrm{P}_{\mathrm{av}}$ content than GL and $\mathrm{PF}$ (Table 5).

Exchangeable $K\left(\mathrm{~K}_{\text {exch }}\right)$ content was not significantly affected by land use, altitude, and the interaction of both (Tables 2). The mean $\mathrm{K}_{\text {exch }}$ obtained in all sampled land use types across the topography was classified as low for the study watershed according to the rating of EthioSIS [56].

3.4. Correlation Analysis. The correlation values showed an apparent association of the parameters with each other. The correlation analyses between SOM with other soil parameters show that the existence of positive and strong association with TP $(r=0.89, p<0.001)$, with soil MC and EC 
( $r=0.83, p<0.001)$, with TN $(r=0.75, p<0.001)$, and with clay content $(r=0.68, p<0.001)$. Pearson coefficient correlation analysis also shows that $\mathrm{BD}$ is inversely correlated with SOM $(r=-0.89, p<0.001)$, TN $(r=-0.71, p<0.001)$, and clay content $(r=-0.68, p<0.001)$ (Figure 7$)$ but had a direct relationship with sand content and $\mathrm{P}_{\mathrm{av}}(r=0.84$, $p<0.01$, and $r=0.56, p<0.05$, respectively). The significant negative associations of sand and BD with SOC and SOM showed that conditions that favor increasing sand fractions and soil compaction (high BD) reduce SOC and SOM status. In turn, these processes reduce soil fertility levels that have a direct relationship with food security, indicating that a change in $\mathrm{BD}$ is associated with changes in SOM, clay, and sand content.

\section{Conclusions}

Understanding soil properties associated with land use and topographical attributes is vital for modeling soil-landscape relationships and establishing sustainable on-field management practices. Increased nutrient mining, soil erosion, and limited nutrient management have led to declining soil quality and reduced productivity in many parts of Ethiopia, which is more pronounced in highly rugged agrarian landscapes where land use influences and topographic variation dominate. In this regard, knowledge of soil properties associated with land use and altitudinal attributes is vital for establishing sustainable site-specific management practices. Therefore, this paper presents a study on the land use type and altitudinal gradient on selected soil physicochemical parameters in the Ayiba watershed, northern Ethiopia.

The variance results analysis shows that the combined effects of land use and variation in the altitudinal gradient caused a significant change in BD, TP, pH-water $(1: 2.5)$, EC, SOM, SOC, TN, and $\mathrm{P}_{\mathrm{av}}$ in the soil of the Ayiba watershed. The result also revealed that BL and CL's soils had the lowest SOM, SOC, and TN contents. On the other hand, soils of GL and PF had higher values of SOM, SOC, and TN contents. Thus, converting the degraded barren lands into protected lands/exclosures can increase these important soil quality parameters, but the reverse has a negative impact. Especially, expansion of cultivation into steep slopes and marginal areas causes severe loss of soil quality. Moreover, most measured soil parameters in the watershed are higher in the lower landscape position and relatively low in the upper landscape position where soil erosion is maximum due to its rugged nature. Compared to the critical values set, the different land use types and topographic positions' measured soil physicochemical levels were low to optimum status. Given this, the conversion of natural forest or grassland to cultivation land and degraded barren land subjected to degradation of soil physicochemical properties, thereby ruining soil quality. Therefore, identifying appropriate land use and management practices is of utmost importance to keep soil health sustainably in the study watershed.

In general, the variation in soil physicochemical properties in the Ayiba watershed is not only related to the conversion of land use and topographic variation but also related to other factors including vegetation removal, complete removal of crop residue, and overgrazing, and the decline of fallowing is obvious, leading to soil degradation and loss of productivity. Additionally, livestock dung is baked into a dung cake and burned as household fuel, denying the soil an important nutrient and organic matter source. The most dangerous cropping practices that should change into other appropriate land use systems are the marginal and steep slope cultivated areas'. Therefore, to reverse soil degradation, further research on soil quality indicators on landscape-based should be evaluated and integrated into land use planning for sustainable land resource management practice in the Ayiba watershed.

\section{Data Availability}

Data used in this manuscript are available upon request.

\section{Conflicts of Interest}

The authors declare that they have no conflicts of interest or personal relationships that could have influenced the work reported in this paper.

\section{Authors' Contributions}

WS was involved in conceptualization, methodology, formal analysis, investigation, data curation, writing the original draft, and visualization. EE was involved in conceptualization, methodology, supervision, fund acquisition, writing the review, and editing. GG was involved in conceptualization, methodology, supervision, fund acquisition, data curation, writing the review, and editing.

\section{Acknowledgments}

The authors thank the Mekelle University CASCAPE Project (funding for Ph.D. study) for funding this study. The authors are also very grateful to all farmers in the study area who allowed them to conduct their research on their vicinity.

\section{References}

[1] B. A. Miheretu and A. A. Yimer, "Spatial variability of selected soil properties in relation to land use and slope position in Gelana sub-watershed, Northern highlands of Ethiopia," Physical Geography, vol. 39, no. 3, pp. 230-245, 2018.

[2] H. Worku, "Impact of physical soil and water conservation structure on selected soil physicochemical properties in gondar zuriya woreda," Resources and Environment, vol. 7, pp. 40-48, 2017.

[3] G. Yihenew, A. Fentanesh, and A. Solomon, "The effects of land use types, management practices and slope classes on selected soil physico-chemical properties in Zikre watershed, North-Western Ethiopia," Environmental Systems Research, vol. 4, p. 3, 2015.

[4] E. Elias, "Selected chemical properties of agricultural soils in the Ethiopian highlands: a rapid assessment," South African Journal of Plant and Soil, vol. 36, no. 2, pp. 153-156, 2019. 
[5] A. M. Gelaw, B. R. Singh, and R. Lal, "Soil organic carbon and total nitrogen stocks under different land uses in a semi-arid watershed in Tigray, Northern Ethiopia," Agriculture, Ecosystems \& Environment, vol. 188, pp. 256-263, 2014.

[6] M. Guadie, E. Molla, M. Mekonnen, and A. Cerdà, "Effects of soil bund and stone-faced soil bund on soil physicochemical properties and crop yield under rain-fed conditions of northwest Ethiopia," Land, vol. 9, no. 1, p. 13, 2020.

[7] N. Haregeweyn, A. Tsunekawa, J. Poesen et al., "Comprehensive assessment of soil erosion risk for better land use planning in river basins: case study of the Upper Blue Nile River," Science of The Total Environment, vol. 574, pp. 95108, 2017.

[8] B. Lema, F. Kebede, S. Mesfin, I. Fitiwy, and Z. Abraha, "Use of the revised universal soil loss equation (RUSLE) for soil and nutrient loss estimation in long-used rainfed agricultural lands, North Ethiopia," Physical Geography, vol. 37, no. 3-4, pp. 276-290, 2016.

[9] S. Damene, L. Tamene, and P. L. G. Vlek, "Performance of exclosure in restoring soil fertility: a case of Gubalafto district in North Wello Zone, northern highlands of Ethiopia," Catena, vol. 101, pp. 136-142, 2013.

[10] G. Girmay and B. Singh, "Changes in soil organic carbon stocks and soil quality: land-use system effects in northern Ethiopia," Acta Agriculturae Scandinavica, Section B-Soil \& Plant Science, vol. 62, pp. 519-530, 2012.

[11] K. Hurni, G. Zeleke, M. Kassie et al., "Soil degradation and sustainable land management in the rainfed agricultural areas of Ethiopia: an assessment of the economic implications," Report for the Economics of Land Degradation Initiative, vol. 62, 2015.

[12] L. Tamene, Z. Adimassu, J. Ellison et al., "Mapping soil erosion hotspots and assessing the potential impacts of land management practices in the highlands of Ethiopia," Geomorphology, vol. 292, pp. 153-163, 2017.

[13] H. Asresie, T. Mekonnen, T. Molla et al., "Validation of minimum tillage best practice on Maize production in Amhara region," Scaling Innovations and Agricultural Best Practices in Ethiopia: Exprience and Challenge, vol. 2, 2015.

[14] M. Bekunda, N. Sanginga, and P. L. Woomer, "Chapter fourrestoring soil fertility in sub-sahara Africa," Advances in Agronomy, vol. 108, pp. 183-236, 2010.

[15] D. Pomeroy, J. Maitima, H. Lyaruu et al., The Land Use Change, Impacts and Dynamics Project Working Paper Number: 42, International Livestock Research Institute, Nirobi, Kenya, 2009.

[16] L. N. Gachimbi, Technical Report on Soil Survey and Sampling: Loitokitok Dvision, Kajiado District, Kenya, International Livestock Research Institue, Nirobi, Kenya, 2002.

[17] T.-G. Vågen, R. Lal, and B. R. Singh, "Soil carbon sequestration in sub-Saharan Africa: a review," Land Degradation \& Development, vol. 16, no. 1, pp. 53-71, 2005.

[18] E. Elias, P. F. Okoth, and E. M. A. Smaling, "Explaining bread wheat (Triticum aestivum) yield differences by soil properties and fertilizer rates in the highlands of Ethiopia," Geoderma, vol. 339, pp. 126-133, 2019.

[19] P. A. Sanchez, "ECOLOGY: soil fertility and hunger in Africa," Science, vol. 295, no. 5562, pp. 2019-2020, 2002.

[20] A. H. Cambule, Assessment of soil organic carbon stocks in the Limpopo National Park: from legacy data to digital soil mapping, 2013.

[21] X. Fang, Z. Xue, B. Li, and S. An, "Soil organic carbon distribution in relation to land use and its storage in a small watershed of the Loess Plateau, China," Catena, vol. 88, no. 1, pp. 6-13, 2012.

[22] J. Wang, B. Fu, Y. Qiu, and L. Chen, "Soil nutrients in relation to land use and landscape position in the semi-arid small catchment on the loess plateau in China," Journal of Arid Environments, vol. 48, no. 4, pp. 537-550, 2001.

[23] M. Mathewos, "Assessment of selected soil physicochemical properties on different land-use systems and landscape positions at Hamesa watershed, Wolayita zone, Southern Ethiopia," Journal of Soil Science Environmental Management, vol. 11, pp. 122-130, 2020.

[24] F. Yimer, "Effect of landscape positions on soil properties in an agricultural land A transect study in the main rift valley area of Ethiopia," Journal of Science Development, vol. 5, pp. 21-31, 2017.

[25] M. Aitkenhead and M. Coull, "Mapping soil profile depth, bulk density and carbon stock in Scotland using remote sensing and spatial covariates," European Journal of Soil Science, vol. 71, no. 4, pp. 553-567, 2020.

[26] C. Hu, A. Wright, and G. Lian, "Estimating the spatial distribution of soil properties using environmental variables at a catchment scale in the loess hilly area, China," International Journal of Environmental Research and Public Health, vol. 16, no. 3, p. 491, 2019.

[27] J. Seibert, J. Stendahl, and R. Sørensen, "Topographical influences on soil properties in boreal forests," Geoderma, vol. 141, no. 1-2, pp. 139-148, 2007.

[28] F. Yimer, S. Ledin, and A. Abdelkadir, "Soil property variations in relation to topographic aspect and vegetation community in the south-eastern highlands of Ethiopia," Forest Ecology and Management, vol. 232, no. 1-3, pp. 90-99, 2006.

[29] U. Amuyou and K. Kotingo, "Toposequence analysis of soil properties of an agricultural field in the Obudu Mountain slopes, cross river state-Nigeria," European Journal of Physical Agricultural Sciences, vol. 3, 2015.

[30] J. E. Moeslund, L. Arge, P. K. Bøcher et al., "Topographically controlled soil moisture drives plant diversity patterns within grasslands," Biodiversity and Conservation, vol. 22, no. 10, pp. 2151-2166, 2013.

[31] P. Ezeaku and F. Eze, "Effect of land use in relation to slope position on soil properties in a semi-humid Nsukka area, Southeastern Nigeria," Journal Agricultural Research, vol. 52, pp. 369-381, 2014.

[32] D. Dessalegn, S. Beyene, N. Ram, F. Walley, and T. S. Gala, "Effects of topography and land use on soil characteristics along the toposequence of Ele watershed in southern Ethiopia," Catena, vol. 115, pp. 47-54, 2014.

[33] T. Negasa, H. Ketema, A. Legesse, M. Sisay, and H. Temesgen, "Variation in soil properties under different land use types managed by smallholder farmers along the toposequence in southern Ethiopia," Geoderma, vol. 290, pp. 40-50, 2017.

[34] V. A. Tellen and B. P. Yerima, "Effects of land use change on soil physicochemical properties in selected areas in the North West region of Cameroon," Environmental Systems Research, vol. 7, p. 3, 2018.

[35] T. Bizuhoraho, A. Kayiranga, N. Manirakiza, and K. A. Mourad, "The effect of land use systems on soil properties; A case study from Rwanda," Sustainable Agriculture Research, vol. 7, no. 2, pp. 30-40, 2018.

[36] J. G. Guzman and M. M. Al-Kaisi, "Landscape position effect on selected soil physical properties of reconstructed prairies 
in southcentral Iowa," Journal of Soil and Water Conservation, vol. 66, no. 3, pp. 183-191, 2011.

[37] S. Beyene, "Topographic positions and land use impacted soil properties along Humbo Larena-Ofa Sere toposequence, Southern Ethiopia," Journal of Soil Science Environmental Management, vol. 8, pp. 135-147, 2017.

[38] D. Panday, R. B. Ojha, D. Chalise, S. Das, and B. Twanabasu, "Spatial variability of soil properties under different land use in the Dang district of Nepal," Cogent Food Agriculture Food Security, vol. 5, 2019.

[39] A. De Stefano and M. G. Jacobson, "Soil carbon sequestration in agroforestry systems: a meta-analysis," Agroforestry Systems, vol. 92, pp. 285-299, 2018.

[40] A. Majule, A Study on Land Use Types, Soils and Linkage between Soils and Biodiversity along the Slopes of Mt, Kilimanjaro, Tanzania, TZ, USA, 2003.

[41] S. B. Misana, A. E. Majule, and H. V. Lyaruu, Linkages Between Changes in Land Use, Biodiversity and Land Degradation on the Slopes of Mount Kilimanjaro, Tanzania, Kenya International Livstock Research Institute, Nirobi, Kenya, 2003.

[42] K. McLauchlan, "The nature and longevity of agricultural impacts on soil carbon and nutrients: a review," Ecosystems, vol. 9, no. 8, pp. 1364-1382, 2006.

[43] B. Yu, P. Stott, X. Y. Di, and H. X. Yu, "Assessment of land cover changes and their effect on soil organic carbon and soil total nitrogen in Daqing Prefecture, China," Land Degradation \& Development, vol. 25, no. 6, pp. 520-531, 2014.

[44] D. A. Ussiri and R. Lal, Land management effects on carbon sequestration and soil properties in reclaimed farmland of eastern Ohio, 2013.

[45] D. Sattler, L. T. Murray, A. Kirchner, and A. Lindner, "Influence of soil and topography on aboveground biomass accumulation and carbon stocks of afforested pastures in South East Brazil," Ecological Engineering, vol. 73, pp. 126131, 2014.

[46] E. Elias, Soils of the Ethiopian Highlands: Geomorphology and Properties, ALTERA Wageningen University Research Centre, The Netherlands, 2016.

[47] NMSAE, Estimated Temperature and Rain Fall Data of Ayiba Watershed, NMSAE (National Meteorological Service Agency of Ethiopia, Addis Ababa, 2018.

[48] M. Alkan, M. Oruc, Y. Yildirim, D. Z. Seker, and K. Jacobsen, "Monitoring spatial and temporal land use/cover changes; a case study in western black sea region of Turkey," Journal of the Indian Society of Remote Sensing, vol. 41, no. 3, pp. 587-596, 2013.

[49] S. K. Maiti, "Handbook of methods in environmental studies," ABD Publications, vol. 2, 2003.

[50] J. Anderson and J. Ingram, "Tropical soil biology and fertility," A Handbook of Methods, vol. 2, 1993.

[51] L. P. Van Reeuwijk, "Procedures for soil analysis," International Soil Reference and Information Centre (ISRIC), vol. 2, 2006.

[52] E. Ben-Dar and A. Banin, "Determination of organic matter in arid-zone soils using a simple loss-on-ignition method," $A$ Handbook of Methods, vol. 20, pp. 5-16, 1989.

[53] N. C. Brady and R. R. Weil, The nature and properties of soils, 2002.

[54] L. B. Guo and R. M. Gifford, "Soil carbon stocks and land use change: a meta analysis," Global Change Biology, vol. 8, no. 4, pp. 345-360, 2002.
[55] R Core Team, R: A Language and Environment for Statistical Computing, The R Foundation for Statistical Computing Platform, Vienna, 2019.

[56] E. Karltun, M. Tekalign, B. Taye, G. Sam, and K. Selamyihun, Towards improved fertilizer recommendations in Ethiopia - nutrient indices for categorization of fertilizer blends from Ethio-SIS woreda soil inventory data: a Discussion paper, 2013.

[57] E. Elias, "Characteristics of Nitisol profiles as affected by land use type and slope class in some Ethiopian highlands," Environmental Systems Research, vol. 6, p. 20, 2017.

[58] M. Tufa, A. Melese, and W. Tena, "Effects of land use types on selected soil physical and chemical properties: the case of Kuyu District, Ethiopia," Eurasian Journal of Soil Science (Ejss), vol. 8, no. 2, pp. 94-109, 2019.

[59] M. A. Wubie and M. Assen, "Effects of land cover changes and slope gradient on soil quality in the Gumara watershed, Lake Tana basin of North-West Ethiopia," Modeling Earth Systems and Environment, vol. 6, no. 1, pp. 85-97, 2020.

[60] L. de la Cruz-Amo, G. Bañares-de-Dios, V. Cala et al., Tradeoffs among aboveground, belowground, and soil organic carbon stocks along altitudinal gradients in andean tropical montane forests, 2020.

[61] Y. Gebreselassie, F. Anemut, and S. Addis, "The effects of land use types, management practices and slope classes on selected soil physico-chemical properties in Zikre watershed, North-Western Ethiopia," Environment and Resources, vol. 4, no. 3, pp. 1-7, 2015.

[62] A. Belayneh, Effect of land use/cover on selected, 2009.

[63] L. Mulugeta, Effects of land use changes on soil quality and native flora degradation and restoration in the highlands of Ethiopia: implication for sustainable land management, 2004.

[64] G. Charan, V. Bharti, S. Jadhav et al., "Altitudinal variations in soil physico-chemical properties at cold desert high altitude," Journal of Soil Science and Plant Nutrition, vol. 13, pp. 267-277, 2013.

[65] G. Bore and B. Bedadi, "Impacts of land use types on selected soil physico-chemical properties of Loma Woreda, Dawuro Zone, Southern Ethiopia," Science, Technology Arts Research Journal, vol. 4, pp. 40-48, 2015.

[66] E. Sakin, "Organic carbon organic matter and bulk density relationships in arid-semi arid soils in Southeast Anatolia region," Science, Technology Arts Research Journal, vol. 11, pp. 1373-1377, 2012.

[67] A. Lelisa and A. Abebaw, "Study on selected soil physicochemical properties of rehabilitated degraded bare land: the case of Jigessa rehabilitation site, Borana zone, Ethiopia," Global Journal of Advanced Research, vol. 3, p. 354, 2016.

[68] S. Pei, H. Fu, and C. Wan, "Changes in soil properties and vegetation following exclosure and grazing in degraded Alxa desert steppe of Inner Mongolia, China," Agriculture, Ecosystems \& Environment, vol. 124, no. 1-2, pp. 33-39, 2008.

[69] X.-G. Li, Z.-F. Wang, Q.-F. Ma, and F.-M. Li, "Crop cultivation and intensive grazing affect organic $\mathrm{C}$ pools and aggregate stability in arid grassland soil," Soil and Tillage Research, vol. 95, no. 1-2, pp. 172-181, 2007.

[70] Y. Li, X. Zhou, J. R. Brandle, T. Zhang, Y. Chen, and J. Han, "Temporal progress in improving carbon and nitrogen storage by grazing exclosure practice in a degraded land area of China's Horqin Sandy Grassland," Agriculture, Ecosystems \& Environment, vol. 159, pp. 55-61, 2012.

[71] J. Singh, A. Salaria, and A. Kaul, "Impact of soil compaction on soil physical properties and root growth: a review," 
International Journal of Food, Agriculture and Veterinary Sciences, vol. 5, pp. 23-32, 2015.

[72] Y.-Z. Su, H.-L. Zhao, T.-H. Zhang, and X.-Y. Zhao, "Soil properties following cultivation and non-grazing of a semiarid sandy grassland in northern China," Soil and Tillage Research, vol. 75, no. 1, pp. 27-36, 2004.

[73] A. Shiferaw, F. Yimer, and S. Tuffa, "Changes in soil organic carbon stock under different land use types in semiarid Borana rangelands: implications for $\mathrm{CO}_{2}$ emission mitigation in the rangelands," Science, Technology Arts Research Journal, vol. 9, p. 254, 2019.

[74] F. Raiesi and M. Riahi, "The influence of grazing exclosure on soil $\mathrm{C}$ stocks and dynamics, and ecological indicators in upland arid and semi-arid rangelands," Ecological Indicators, vol. 41, pp. 145-154, 2014.

[75] W. Mekuria, E. Veldkamp, M. Haile, J. Nyssen, B. Muys, and K. Gebrehiwot, "Effectiveness of exclosures to restore degraded soils as a result of overgrazing in Tigray, Ethiopia," Journal of Arid Environments, vol. 69, no. 2, pp. 270-284, 2007.

[76] P. Hazelton and B. Murphy, Interpreting Soil Test Results: What Do All the Numbers Mean?, CSIRO Publishing, Berlin, Germany, 2016.

[77] J. D. Ahmad and S. Somaiah, "Altitudinal variation of soil organic carbon stocks in temperate forests of Kashmir Himalayas, India," Environ Monit Assess, vol. 187, p. 11, 2015.

[78] P. Gupta, Plant Analysis. Soil, Plant, Water and Fertilizer Analysis, Agrobios, Jodhpur, India, 2004.

[79] N. C. Brady and R. R. Weil, The Nature and Properties of Soils, Pearson, Jodhpur, India, 2016.

[80] A. Chimdi, H. Gebrekidan, K. Kibret, and A. Tadesse, "Status of selected physicochemical properties of soils under different land use systems of Western Oromia, Ethiopia," Environmental Systems Research, vol. 2, no. 3, pp. 57-71, 2012.

[81] F. Yimer, G. Alemu, and A. Abdelkadir, "Soil property variations in relation to exclosure and open grazing land use types in the Central Rift Valley area of Ethiopia," Environmental Systems Research, vol. 4, p. 17, 2015.

[82] J. Tang, A. J. Davy, D. Jiang et al., "Effects of excluding grazing on the vegetation and soils of degraded sparse-elm grassland in the Horqin Sandy Land, China," Agriculture, Ecosystems \& Environment, vol. 235, pp. 340-348, 2016.

[83] B. Zerga, "Ecological impacts of Eucalyptus plantation in eza wereda, Ethiopia," Environmental Systems Research, vol. 3, no. 4, pp. 2408-7254, 2015.

[84] B. Yerima and E. Van Ranst, Introduction to Soil Science: Soils of the Tropics, Trafford Publishing, Victoria, 2005.

[85] A. Mohammed, G. Heluf, P. A. Leroux, and C. H. Barker, "Soils of Jelo micro-catchment in the Chercher highlands of eastern Ethiopia: I. Morphological and physio-chemical properties," Ethiopian Journal of Natural Resources, vol. 7, pp. 55-81, 2005.

[86] S. Mohammed, The Effect of Organic Matter on Runoff, Soil Loss and Crop Yield at Anjeni, Alemaya University, West Gojjam, Ethiopia, 2003.

[87] R. Kizilkaya and O. Dengiz, "Variation of land use and land cover effects on some soil physico-chemical characteristics and soil enzyme activity," Zemdirbyste-Agriculture, vol. 97, pp. 15-24, 2010.

[88] S. Shazia, Y. Muhammad, A. Alia, and H. Syed, "Impact of altitude on soil physical and chemical properties in Sra Ghurgai (takatu mountain range) Quetta, balochistan,"
International Journal of Scientific \& Engineering Research, vol. 5, no. 3, 2014.

[89] A. Kidanemariam, H. Gebrekidan, T. Mamo, and K. Kibret, "Impact of altitude and land use type on some physical and chemical properties of acidic soils in Tsegede Highlands, Northern Ethiopia," Open Journal of Soil Science, vol. 2, no. 3, p. 223, 2012.

[90] J. Panthi, Altitudinal Variation of Soil Fertility: A Case Study from Langtang National Park, Central Department of Environmental Science Tribhuvan University Kathmandu, Nepal, 2010.

[91] H. A., G. Heluf, B. Bobe, and A. Enyew, "Fertility status of soils under different land uses at Wujiraba Watershed, North-Western Highlands of Ethiopia," Agriculture, Forestry and Fisheries, vol. 3, no. 5, pp. 410-419, 2014.

[92] C. L. C. van Beek, E. Elias, Y. Gbrelassie et al., "Soil organic matter depletion as a major threat to agricultural intensification in the highlands of Ethiopia," Ethiopian Journal of Science and Technology, vol. 11, pp. 271-285, 2018.

[93] V. N. Nsalambi, "Effect of landscape position on the concentration and distribution of soil carbon fractions at Busby forest in central Missouri," Transactions of the kansas Academy of Science, vol. 121, no. 3-4, pp. 377-385, 2018.

[94] D. Jendoubi, H. Liniger, and C. Ifejika Speranza, "Impacts of land use and topography on soil organic carbon in a Mediterranean landscape (north-western Tunisia)," Soil, vol. 5, no. 2, pp. 239-251, 2019.

[95] Y. T. Delelegn, W. Purahong, A. Blazevic et al., "Changes in land use alter soil quality and aggregate stability in the highlands of northern Ethiopia," Scientific Reports, vol. 7, 2017.

[96] F. Yimer, S. Ledin, and A. Abdelkadir, "Changes in soil organic carbon and total nitrogen contents in three adjacent land use types in the Bale Mountains, south-eastern highlands of Ethiopia," Forest Ecology and Management, vol. 242, no. 2-3, pp. 337-342, 2007.

[97] G. Gurmu, "Soil organic matter and its role in soil health and crop productivity improvement," Forest Ecology and Management, vol. 7, no. 7, pp. 475-483, 2019.

[98] M. A. Tesfaye, F. Bravo, R. Ruiz-Peinado, V. Pando, and A. Bravo-Oviedo, "Impact of changes in land use, species and elevation on soil organic carbon and total nitrogen in Ethiopian Central Highlands," Geoderma, vol. 261, pp. 7079, 2016.

[99] T. Tolessa and F. Senbeta, "The extent of soil organic carbon and total nitrogen in forest fragments of the central highlands of Ethiopia," Journal of Ecology and Environment, vol. 42 , p. 20, 2018.

[100] J. Walworth, Nitrogen in the Soil and the Environment, The University of Arizona, Tucson, AZ, USA, 2013.

[101] S. F. Fentie, K. Jembere, E. Fekadu, and D. Wasie, "Land use and land cover dynamics and properties of soils under different land uses in the tejibara watershed, Ethiopia," The Scientific World Journal, vol. 2020, 2020.

[102] M. Liu, D. A. N. Ussiri, and R. Lal, "Soil organic carbon and nitrogen fractions under different land uses and tillage practices," Communications in Soil Science and Plant Analysis, vol. 47, no. 12, pp. 1528-1541, 2016.

[103] USDA NRCS, "Carbon to nitrogen ratios in cropping systems," USDA Natural Resources Conservation Service, Soils, vol. 47, 2020.

[104] Y. Gebreslassie and G. Ayanna, "Effects of different land use systems on selected physico-chemical properties of soils in 
Northwestern Ethiopia," Journal of Agricultural Science, vol. 5, p. 112, 2013.

[105] E. Elias and G. Agegnehu, "Mineralogical and physicochemical properties of nitisols in the Ethiopian highlands," Ethiopian Journal of Agricultural Sciences, vol. 30, pp. 97119, 2020.

[106] E. Zewdie, Properties of Major Agricultural Soils of Ethiopia, Lambert Academic Publishing, London, UK, 2013.

[107] P.-T. Guo, W. Wu, H.-B. Liu, and M.-F. Li, "Effects of land use and topographical attributes on soil properties in an agricultural landscape," Soil Research, vol. 49, no. 7, pp. 606-613, 2011.

[108] A. Moges, M. Dagnachew, and F. Yimer, "Land use effects on soil quality indicators: a case study of abo-wonsho southern Ethiopia," Applied and Environmental Soil Science, vol. 2013, p. 784989, 2013

[109] Y. Cheng, P. Li, G. Xu, Z. Li, S. Cheng, and H. Gao, "Spatial distribution of soil total phosphorus in Yingwugou watershed of the Dan River, China," Catena, vol. 136, pp. 175-181, 2016. 